\title{
Decoupling: Marital Violence and the Struggle to Divorce in China ${ }^{1}$
}

\author{
Ethan Michelson \\ Indiana University Bloomington
}

\begin{abstract}
An analysis of adjudicated divorce decisions in two Chinese provinces reveals the extent to which and the reasons why Chinese courts subvert the global legal norms they symbolically embrace. In China, uncontested no-fault divorces are readily attainable outside the court system. Courts, by contrast, granted divorces in fewer than half of the cases they adjudicated. Despite an abundance of formal legal mechanisms designed to provide relief to victims of marital abuse, a plaintiff's claim of domestic violence did not increase the probability a court granted a divorce request. Chinese courts' highly institutionalized practice of denying first-attempt divorce petitions and granting divorces on subsequent litigation attempts disproportionately impacts women and has spawned a sizable population of female marital-violence refugees. These findings carry substantive and theoretical implications concerning the limits and possibilities of the local penetration of global legal norms.
\end{abstract}

A 27 -year-old female plaintiff from a village in Huojia County, Henan Province, seeking to divorce her husband in court supported her claim of marital abuse with medical documentation showing a diagnosis of a vertebral fracture. In his defense statement, her husband rebutted, "I did not beat the

${ }^{1}$ This research came to fruition only because of the generous support of Benjamin Lieb-
man, Rachel Stern, and Alice Wang, who collected and shared the raw data from Henan
Province. I am grateful to Ke Li, my former student, for reversing roles and teaching me
much about Chinese divorce litigation and serving as a critically helpful sounding board
as I worked through the data. All errors are my own. Hai Hu and Zuoyu Tian provided
key technical assistance with the collection and preparation of data. Additional thanks go
to Keera Allendorf, Tim Bartley, Gardner Bovingdon, Jinting Deng, Vitor Dias, Sara
Friedman, Kathryn Hendley, Padraic Kenney, Jayanth Krishnan, Wen-ling Liu, Scott

(C) 2019 by The University of Chicago. All rights reserved.

0002-9602/2019/12502-0001\$10.00

AJS Volume 125 Number 2 (September 2019): 325-381

325 
plaintiff very often, and I do not consent to divorce." In its holding, the court stated, "After marrying, plaintiff and defendant fought over trivial matters, which even triggered physical beatings. However, on the basis of this trial, marital affection has not declined to the level of total breakdown. There is still hope for them to reconcile, reunite, and continue living together" (Decision 216758, Huojia County People's Court, Henan Province, October 12, 2009).

Chinese courts adjudicate over 500,000 contested divorce petitions per year (Ministry of Civil Affairs of China, various years), perhaps one quarter of which, like the above case, involve claims of violence and other forms of abuse (Chen and Duan 2012; Li 2015b). Such cases, which are initiated more often than not by women, more often than not result, also like the above case, in a court ruling to preserve rather than to dissolve the marriage (Ministry of Civil Affairs of China, various years; Xu 2007). In this article, using a new and underutilized source of court decisions, I show that Chinese courts' long-standing practice of denying divorce requests on the first attempt (He 2009) has intensified since the mid-2000s and that China's judicial clampdown on divorce has disproportionately impacted women.

Sociologists have argued that country-level divorce rates are unleashed by both the ratification of international treaties that promote women's rights and gender-equal national divorce laws that conform to global norms and values (Wang and Schofer 2018). In China, a more than threefold surge in the annual volume of divorces since the year 2000 is attributable almost entirely to an explosion in the routine, administrative processing of uncontested, mutual consent divorces outside the court system in local civil affairs bureaus (Ministry of Civil Affairs of China, various years). It would be a mistake, however, to conclude that divorce is increasingly accessible and routine for everyone. We will see in this article that the doubling of China's crude divorce rate from 1.5 to 3.0 per 1,000 population between 2006 and 2015 (Ministry of Civil Affairs of China, various years; Zhou 2017) obscures durable local institutional forces militating against China's own laws promoting gender equality and the freedom of divorce.

Although courts contribute only a small share of all of China's more than 4 million divorces processed annually in recent years (Ministry of Civil Affairs of China 2018, various years), they are the only place where people can take

Long, Peter Lorentzen, Trent Mize, Christiana Ochoa, Brian Powell, Benjamin Read, Fabio Rojas, Catherine Taylor, Suisui Wang, Deborah Widiss, John Yasuda, Jianing Ying, and Lianhan Zhang. Portions of this article will also appear in Decoupling: Gender Injustice in China's Divorce Courts, forthcoming from Cambridge University Press in 2020. Finally, I am grateful to the $A J S$ reviewers for their extraordinarily helpful suggestions. Direct correspondence to Ethan Michelson, Department of Sociology, Indiana University, Bloomington, Indiana 47405. E-mail: emichels@indiana.edu 
contested, unilateral, ex parte divorce requests that often stem from domestic violence. Courts contribute only a small and shrinking share of divorces in part because they have become increasingly averse to granting adjudicated divorces. Between 2000 and 2016, the annual number of divorce requests courts granted through adjudication shrank by $11 \%$, while the annual number of divorce requests denied by court adjudication rose by $176 \%$ (Ministry of Civil Affairs of China, various years). Divorce in China both illuminates and obfuscates the limits and possibilities of "world society's" influence on the freedom of divorce.

By both design and coincidence, Chinese family law embodies core world society norms: general world society norms of secular individualism, universalism, and scientific rationality and particular world society norms of equal rights to marriage and divorce (Boli and Thomas 1997; Meyer et al. 1997; Boyle and Meyer 1998; Boli and Lechner 2001; Wotipka and Ramirez 2008; Wang and Schofer 2018). As we will see, in the Chinese context of divorce litigation, world society norms coexist with and are neutralized by orthogonal institutional logics of social stability and judicial efficiency. I argue that Chinese judges' tendency to deny first-attempt divorce petitions and to grant subsequent petitions - a phenomenon I call the "divorce twofer"stems from three institutional sources unrelated to world society: a political ideology that emphasizes family preservation, heavy court dockets, and performance evaluation systems that motivate judges to support political priorities. I also argue that judges' unequal treatment of female and male plaintiffs stems from a fourth institutional logic inconsistent with world society: patriarchy.

For women seeking relief from abusive husbands, courts are not the solution but rather part of the problem. I argue that the key to understanding the marginal relevance of marital violence in Chinese divorce adjudication despite its importance in official state rhetoric and black-letter law lies in countervailing legal standards, institutional norms, and practices that overwhelm China's more prominent ceremonial commitments to protect vulnerable women. By privileging a no-fault legal standard of the "breakdown of mutual affection" over competing fault-based legal standards of spousal wrongdoing, including domestic violence, courts themselves are an obstacle to women's freedom of divorce.

In China, fault-based legal standards, known as "faultism," are consistent with global norms about protecting female victims of marital violence and support granting divorces in cases such as the one in the opening vignette. Competing no-fault legal standards, known as "breakdownism," are consistent with local norms about protecting the institution of marriage, social stability, and the interests of judges and support denying divorces in such cases. China thus offers an opportunity to assess directly the relative importance of competing norms and practices - some consistent with and some antithetical 
to world society models. Scholars in the world society tradition, sometimes referred to as the "Stanford school of sociological institutionalism" (True and Mintrom 2001; Haley and Haley 2016), focus on the "strong commonalities in international discourses on a wide range of topics, from human rights to environmentalism" (Schofer et al. 2012, p. 59). To borrow the conceptual language of Heimer (1999) and Edelman (2016), we will see that China's domestic fault-based standards consistent with world society norms are "symbolic laws" containing "symbolic rights" that, in a twist of tragic irony, have largely failed to penetrate its own civil courts, whereas the routine practice of using a countervailing no-fault standard to deny the petitions of plaintiffs seeking to dissolve abusive marriages has largely stuck.

The findings I present from an empirical analysis of almost 150,000 court adjudications of divorce petitions spanning eight years from two Chinese provinces, Henan and Zhejiang, show that courts subvert the very legal principles of divorce rights and gender equality they symbolically embrace. In China, no-fault divorce laws consistent with legitimized global models are perversely used in practice at best to delay and at worst to suppress divorce in general and female-initiated divorce in particular, even when plaintiffs make claims of domestic violence and support them with evidence. Even if most divorce seekers eventually find a way to achieve their goal, justice delayed is justice denied. We will see that the delay and denial of justice is highly gendered.

\section{HOW MARITAL DECOUPLING INFORMS THEORIES OF INSTITUTIONAL DECOUPLING}

Previous research offers clues that might help us make sense of this puzzle of Chinese courts' routine and egregious violations of global legal norms about the freedom of divorce, gender equality, and the protection of the physical security of women. The existing literature points in at least four possible directions of inquiry. First, we could consider the supply of China's domestic laws that address divorce rights and domestic violence (Hudson, Bowen, and Nielsen 2011; Htun and Weldon 2018; Wang and Schofer 2018). This would be a moot exercise given China's massive arsenal of laws and policies rooted in a deep ideological commitment to gender equality common to communist states (Tang and Parish 2000, p. 237; Huang 2005; Cheng and Wang 2018). Just as the "freedom of marriage" came to symbolize the liberation of women from the oppression of arranged marriages, bigamy, and other "feudal" practices, the "freedom of divorce" too became an enshrined legal principle, particularly for purposes of providing relief to women (Palmer 1995, p. 122; Jiang 2009a).

Second, we could consider China's commitment to upholding relevant global legal norms (Hudson et al. 2011; Englehart and Miller 2014; Htun 
and Weldon 2018). As China has signed all seven (and ratified six) core international human rights treaties, including the Convention on the Elimination of All Forms of Discrimination against Women (CEDAW), this too would be a fruitless avenue of inquiry insofar as, by this measure, China appears to have endorsed relevant global legal norms (Runge 2015; Zhao and Zhang 2017). Numerous official reports and white papers document in great detail China's strong pledges and concrete steps it has taken to support international goals concerning the status of women in general and the protection of women against violence in particular, and its ostensible progress fulfilling these commitments (e.g., Information Office of the State Council 2015; Rong 2016; Zhao 2016).

China's on-the-ground judicial practices that subvert its domestic laws and international commitments point to a third literature on "loose coupling" and "radical decoupling" (Hafner-Burton and Tsutsui 2005; Hafner-Burton, Tsutsui, and Meyer 2008), a gap between form and substance, appearance and reality. It has become a sociological truism that largely ritualistic and ceremonial conformity in organizational appearance belies enormous local variation in on-the-ground organizational behavior (Meyer and Rowan 1977; DiMaggio and Powell 1983). Over the past two decades, scholars in the world society tradition have demonstrated the global ubiquity of decoupling, sometimes called "ceremony without substance" (Meyer and Rowan 1977; Frank, Hardinge, and Wosick-Correa 2009; Schofer et al. 2012; Cole 2013).

While most of this literature is devoted to measuring and explaining the global diffusion of standardized scripts governing organizational appearance and behavior, more recent efforts in this tradition have sought to identify mechanisms accounting for cross-national variation in the extent of compliance with and the implementation of legal, policy, and regulatory commitments (Cole 2005; Hafner-Burton and Tsutsui 2005; Pope and Meyer 2016). In other words, a shift has occurred in this literature from describing superficial norm adoption to assessing its impact (Schofer et al. 2012). In our search for explanations for "empty promises" (Hafner-Burton and Tsutsui 2005) to Chinese women seeking to divorce their abusive husbands, we might scrutinize China's bureaucratic capacity to enforce its domestic laws and international commitments (True and Mintrom 2001; Englehart and Miller 2014; Cole 2015; Htun and Weldon 2018). We might consider the availability and character of monitoring mechanisms (Cole 2005). We might consider local values and practices inimical to the reception of global norms, including religious doctrine and misogyny (Boyle, McMorris, and Gómez 2002; Inglehart and Norris 2003; Pierotti 2013; Welzel 2013; Inglehart, Ponarin, and Inglehart 2017; Htun and Weldon 2018; Wang and Schofer 2018). We might consider the strength and autonomy of domestic feminist movements (Htun and Weldon 2018). We might expect to find that, over time, a process of recoupling occurs when "the entire system 'drifts' toward legitimated models" without 
the help of formal enforcement mechanisms (Schofer and Hironaka 2005, p. 27; also see Hafner-Burton and Tsutsui 2005).

We will see that the precise nature of the most salient local obstacles Chinese divorce seekers face is difficult to discern using macrocomparative crossnational research designs common to this literature. In contrast to sociological research in the third literature emphasizing the role of exogenous models, templates, scripts, and blueprints (Frank, Hironaka, and Schofer 2000; Frank, Camp, and Boutcher 2010; Frank and Moss 2017), a fourth literature brings into high relief the less obvious endogenous forces that animate organizational behavior (Heimer 1999; Wimmer 2001; Merry 2006; Dezalay and Garth 2010; Hallett 2010; Pache and Santos 2013; Raynard, Lounsbury, and Greenwood 2013; Bartley and Egels-Zandén 2016; Edelman 2016; Haley and Haley 2016; Bartley 2018). ${ }^{2}$ This fourth literature eschews efforts to draw macroscopic generalizations from superficial country-level indicators and points instead to in-depth, nuanced, contextually specific scrutiny of local processes animating organizational behavior as a potentially fruitful means of explaining the puzzle of decoupling (pun intended) in China's civil courts.

The story that emerges from the evidence I present is about the marginalization and even neutralization of domestic laws consistent with global legal norms protecting the freedom of divorce and the equal rights of women. Although it is a China-specific and divorce-specific story, it points to generalizable conditions of decoupling that may be found in other institutional contexts elsewhere in the world. If we are sufficiently attuned to local institutional pressures and practices, we will likely find durable and even intensifying institutional decoupling in other contexts characterized by the same basic conditions present in the Chinese context of divorce litigation: close symbolic alignment to world society norms and local agents motivated to carry out their charge of upholding countervailing endogenous institutional norms.

I lay the groundwork for my empirical analysis in two steps. First, I establish that China's family laws align closely with world society norms insofar as they champion the freedom of divorce and gender equality. Second, I identify countervailing institutional norms and pressures that at a minimum blunt and at most neutralize the force of these laws inside China's courts.

\section{THE RIGHT TO DECOUPLE}

In this section I provide a schematic overview of laws pertaining to the right to divorce, including the right to relief from domestic violence, and how they are double-edged swords also used in practice to deny gender justice.

\footnotetext{
${ }^{2}$ The word "endogenous" is used synonymously with "local," "domestic," and "indigenous" in much of the institutional literature devoted to untangling "exogenous" and "endogenous" processes and influences (e.g., Cole 2005; Wotipka and Ramirez 2008; Meyer 2010).
} 
Competing Legal Standards for Divorce Breakdownism and Faultism

China is a poster child for laws protecting gender equality and the freedom of divorce. Following the establishment of the People's Republic of China in 1949, the first body of law enacted by the new government was the 1950 Marriage Law, which enshrined the principles of gender equality and the freedom of marriage based on love and consent. In the time since the 1950 and 1980 versions of the Marriage Law, neither of which addressed domestic violence, legal provisions promoting gender equality in general and protecting victims of domestic violence in particular have emerged in a dizzying number of national laws in China (Alford and Shen 2004, p. 242; Chen and Duan 2012; Runge 2015, p. 34; Zhao and Zhang 2017, pp. 194-95; Cheng and Wang 2018). According to the 2008 Guidelines on Judging Marital Cases Involving Domestic Violence, published by a think tank within the Supreme People's Court (SPC), "China has over 69 local laws and regulations to prevent, stop, and prohibit domestic violence" (Article 16). ${ }^{3}$ Moreover, these guidelines cite by name and quote directly from the United Nations' 1993 Declaration on the Elimination of Violence against Women and 2006 SecretaryGeneral's In-Depth Study on All Forms of Violence against Women.

In comparative historical perspective, China was a legal trailblazer in terms of liberal no-fault divorce standards. For over half a century China's laws on the books have allowed divorce when only one spouse wants it. Countervailing against the freedom of divorce, however, were official concerns about its abuse and concomitant policies intended to discourage and limit its exercise. The call to "oppose frivolous divorce" (Chen 2005; Zhang 2009, p. 28; Ma and Luo 2014, p. 39), which reverberates to this day, was justified by the work of Marx and Engels, and by Lenin's famous quip that "it is not at all difficult to understand that the recognition of the right of women to leave their husbands is not an invitation to all wives to do so!" (Liang 1982, p. 19). The Chinese novel Waiting (Jin 2000) is frequently cited to illustrate a "legal system that substantively provides for the freedom of divorce but procedurally prohibits it" (Woo 2001, p. 256; see also Honig and Hershatter 1988, p. 206; Alford and Shen 2004, p. 250; Huang 2005, p. 187).

Although mutual consent has never been an absolute condition of divorce in any Chinese law, in practice it remains a virtual sine qua non of divorce thanks to "breakdownism," a legal test based on the current extent of - and future potential for-marital affection and love. The "breakdown of mutual affection” (感情破裂) standard was added to the 1980 Marriage Law (Article 25) and remains in the 2001 version (Article 32) as follows: "If one party alone desires a divorce, the organization concerned may carry out mediation or the party may appeal directly to a People's Court to start divorce

${ }^{3}$ All translations, including this one, are the author's, with the exception of previously available translations of the Marriage Law. 
proceedings. In dealing with a divorce case, the People's Court shall carry out mediation; in cases of complete breakdown of mutual affection, and when mediation has failed, divorce should be granted."

By adding what appears on the surface to be a variant of standardized global no-fault "irreconcilable differences" standards, the 1980 Marriage Law's breakdownism (破裂主义) appeared to lower barriers to divorce. Paradoxically, however, breakdownism has served to support the deeper legislative spirit of "preventing frivolous divorce." The Marriage Law's promise of unilateral no-fault divorce was in large measure neutralized by its requirement that courts first determine whether a marriage is dead or still viable. Chinese courts are distinguished by the wide discretion they wield to assess the quality of marital relations when deciding to dissolve or preserve marriages. The legislative intent of the breakdownism standard was to allow "the courts both to loosen divorce requirements for those couples whose relationship offered no hope for reconciliation and to tighten them for spouses who sought divorce out of momentary anger" (Huang 2005, p. 187). If one's spouse is unwilling to divorce, wanting out of a marriage is rarely enough, at least on the first attempt ( $\mathrm{Xu} 2007$, p. 204). Scholars have widely decried the practical application of the breakdownism test as a "backward step" (倒退) and an unlawful assault on the freedom of divorce (Jiang 2009a, p. 67; see also Yi and Tong 1998; Ma 2006).

China's fault-based legal standards, known as “faultism” (过错主义; Ma and Luo 2014), are rarely used to grant divorces even when claims of wrongdoing are supported by evidence and affirmed by judges. Article 32 of the 2001 Marriage Law also stipulates that a court should grant a divorce request when any of five itemized fault-based standards, including domestic violence, is satisfied and mediation fails. Marital violence, regardless of which side is at fault, automatically establishes the breakdown of mutual affection and therefore should, according to this legal test, oblige courts to grant a unilateral divorce request (Ma 2006, p. 24). As we will see, however, courts rarely base their decisions on claims of wrongdoing and instead "tend to use the breakdown of mutual affection to justify their decisions" (H. Li 2014, p. 87).

Although, as we will see, a clear plurality, and possibly even a majority, of divorce cases in court are contested on the first attempt, defendants do sometimes (albeit rarely) agree on the divorce itself, even if they challenge the terms of the divorce. According to Article 31 of the Marriage Law, a divorce should be granted if both sides want out. More often than not, judges take mutual consent as evidence of the breakdown of mutual affection and grant the divorce on this basis (Jiang 2009b p. 19; Luo 2016, p. 16). Judges, however, may also deny a divorce petition even when the defendant consents if, for example, they suspect the couple is conspiring to get a "fake divorce" and then to remarry after achieving their illicit goal of escaping debt, 
circumventing restrictions on the purchase of real estate, evading family planning policies, or receiving more housing demolition compensation (Jiang 2009b, p. 19; Tan and Wang 2011; Cai and Qi 2019; Fu and Wang 2019).

If mutual consent is not possible, another way a plaintiff might try to dissolve a bad marriage is to have her spouse declared missing. A missing person declaration from a court provides sufficient statutory grounds for a divorce and thus obviates the need to satisfy the breakdownism standard (Sun 2006, p. 121). In practice, however, courts routinely grant divorces in absentia without first going to the trouble of formally declaring defendants missing. Even if a person seeking a divorce from a missing spouse does not request a missing person declaration, the court must accept the case and serve the defendant with court papers via public notice (公告送达). A defendant is considered to have been served 60 days after a public notice is posted on a public bulletin board or in a newspaper (Sun 2006, p. 122), although in recent years courts' public notices have moved online. It is the court's duty only to serve a defendant with notice of his trial and to make available a copy of the plaintiff's petition; whether or not defendants who have been served show up for their day in court, submit a written response in lieu of appearing in person, or appoint a representative to speak on their behalf is not the court's responsibility and will not affect the court's adjudicatory role (Dong and Ji 2016, p. 89).

An “in absentia public notice divorce trial” (公告离婚, hereafter “public notice trial" for short) is one in which the defendant, whom the plaintiff claimed was missing, failed to respond to a public notice summons. According to judicial opinions issued by the SPC, which carry the force of law, such cases automatically pass the breakdownism test when the defendant has been missing for at least two years and can therefore serve as the statutory basis of a court ruling to grant a divorce (Dong and Ji 2016, pp. 91-92).

Divorce trials with AWOL defendants are concentrated in rural areas, where a large share of able-bodied adults participate in labor migration (Tao and Lu 2012; Xu 2012, p. 42). Many defendants miss their trials not only because of service of process failures, but also because they opt out of them. Even when they receive a summons, defendants commonly fail to submit written statements or make oral defense statements in court (Zeng 2008, p. 161).

Regardless of whether a defendant participates in court proceedings, a physical separation on its own can also be the statutory basis of a court ruling to grant a divorce. The 2001 Marriage Law shrank an earlier statutory no-fault physical separation period from three to two years for first-attempt petitions and retained an earlier one-year separation test following an adjudicated denial (Article 32, item 4). A physical separation claim, however, is subject to the breakdownism test: the plaintiff must prove that the breakdown of mutual affection is the reason for the separation. Strictly speaking, separation due to labor migration, for example, fails to meet the statutory 
conditions for divorce. In practice, however, judges will often grant a divorce after inferring from a two-year separation that the breakdown of mutual affection was its consequence even if it was not its cause (Xu 2012, p. 40).

As we will see, plaintiffs' best chances for getting divorced are either when their spouses consent or when their allegedly missing spouses are served by public notice. Mutual consent and public notice trials greatly boost plaintiffs' chances of success. Owing to the wide discretion judges exercise in determining the amount of love present and possible in the marriage, they typically regard a defendant's unwillingness to divorce as evidence that mutual affection has not broken down. When defendants withhold consent, a plaintiff's unilateral insistence on divorce is close to futile regardless of whether her claim is based on the no-fault breakdownism test of incompatibility or the faultism test of domestic violence (Ma 2006, p. 26; Xu 2007, p. 204). We will see that domestic violence claims have no meaningful bearing on whether a court grants a divorce request and may even be counterproductive.

\section{Standards of Evidence}

According to relevant Chinese legal standards of evidence, the burden of proof is supposed to fall on the defendant to support his rebuttal of the plaintiff's claim of domestic violence (Li, Liu, and Yang 2013, p. 35; Runge 2015 , p. 38). Judges should affirm a claim of domestic violence if the plaintiff submits evidence showing that both an injury occurred and a domestic dispute occurred the same day (Li et al. 2013, p. 35). Although judges are supposed to treat victims' statements as more credible than offenders' (Runge 2015 , p. 38) and to consider the interests of the more vulnerable side when ruling on evidence, in practice the burden of proof tends to fall on the plaintiff according to the more general principle of "whoever makes the claim must prove it" (H. Li 2014, p. 88).

Rarely do judges take plaintiffs at their word when they make claims of domestic violence, especially if the defendant denies the claim (Chen and Duan 2012, p. 36; H. Li 2014, p. 87), even though judges are fully empowered by the SPC to do so on the basis of its 2008 guidelines, which call for privileging victims' statements over defendants' statements in "he said, she said" situations on the premise that "few people would risk the public shame of lying about being beaten and abused by one's spouse" (Article 41; also see Runge 2015 , p. 38). Judges often side with defendants who make statements to the court such as the following: "It's not true. She fell down on her own. Besides, it's not a bone fracture but a herniated disc.... She's the one who grabbed the shovel and, when raising it to hit me, ended up hitting herself on the head. This was a fight over some trifling matter" (Li et al. 2013, p. 34).

Some judges either lack an understanding of or choose to ignore the legal definition of domestic violence. For example, one court held that "the injury 
the defendant caused the plaintiff in an act of momentary agitation is unlawful but not domestic violence" (Li et al. 2013, p. 35). After affirming that the defendant had hit the plaintiff in the face, resulting in a contusion, another court ruled that "evidence submitted to the court by the plaintiff Xiao X proves only that the defendant Wang $\mathrm{X}$ beat the plaintiff one time with insignificant consequences, which counts as everyday marital squabbling and marital conflict with occasional physical fighting but without harm, and which cannot be affirmed as domestic violence" (Zhang 2018, p. 109). In another case, after affirming evidence from police and hospital documentation of the plaintiff's injury, the court ruled that "in the course of living together, the defendant's everyday physical and verbal abuse, which occasionally causes minor bodily injury of no real consequence, cannot be affirmed as domestic violence" (Zhang 2018, p. 109).

Judges exercise similar discretion when considering plaintiffs' claims of physical separation from defendants (Xu 2007, p. 204). Some plaintiffs support claims of physical separation with documentation of a new residence (their own or the defendant's), while many simply rely on their testimony and hope the court will take them at their word (Xu 2012; Luo 2016, p. 22). Meanwhile, plaintiffs' claims of defendants' unknown whereabouts are often supported by similarly shaky evidence, such as defendants' failure to be found when court personnel attempt to serve their court summons at the official addresses listed on their citizen identity cards, letters (of sometimes dubious provenance) from villagers' committees or residents' committees, or witness testimony from neighbors and relatives (Sun 2006, p. 122; Dong and Ji 2016, p. 91; Zhao 2018).

I argue that the key to unlocking the puzzle of the routine denial of divorce petitions in China's courts lies in competing institutional pressures. Competing institutional imperatives prevail in part thanks to judges' wide latitude to apply the arbitrary, ad hoc, and inconsistent evidentiary standards discussed in this section. As we will see in the next section, the institutional imperative for judges to uphold China's domestic laws and commitments to global legal norms is trumped by competing institutional imperatives for judges to uphold the family, maintain social stability, and close cases.

\section{WHY COURT DIVORCE PRACTICES ARE DECOUPLED FROM THE RIGHT TO DECOUPLE}

The decoupling of China's divorce courts from world society models could be a function of technical enforcement impediments (Cole 2015). Given the general ubiquity of "logic pluralism" (Thornton, Ocasio, and Lounsbury 2012, p. 142; Glynn and Raffaelli 2013), however, it could also be a function of closer alignment with alternative and competing local institutional models. Divorce is a microcosm of a more general pattern in China's legal 
system of drifting simultaneously toward and away from global legal norms (Minzner 2011), particularly with respect to gender equality (Chen 2007; Xu

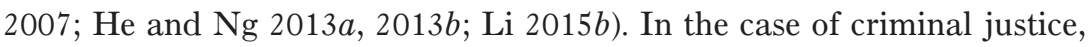
laws on the books protecting the globally institutionalized due process rights of criminal suspects and their defense lawyers - that are consistent with global rule-of-law norms - are overwhelmed by competing normative practices and cognitive scripts rooted in countervailing local institutional legacies (Michelson 2007; Liu and Halliday 2016). In the case of divorce litigation in China, endogenous institutional logics similarly illuminate why courts obstruct the implementation of domestic laws consistent with global legal norms. The following four sets of endogenous institutional norms and pressures prominently at play in China's courts are reasons to expect that judges privilege both breakdownism over faultism and men over women.

\section{Limited Judicial Resources}

According to a core tenet of the Stanford school of sociological institutionalism, the technical requirements of organizational work routines explain at least some measure of loose coupling between ceremonial conformity with globally legitimized norms and substantive organizational activities (Meyer and Rowan 1977). As the argument goes, legal systems around the world conform to the "universal ideal frame" embodied by global legal norms even when resource limitations and technical constraints limit their realization in practice (Boyle and Meyer 1998, pp. 217-18, 220). Evidence suggests that a state's bureaucratic capacity to fulfill its ceremonial commitments facilitates their implementation (Cole 2015). The case of Chinese courts appears to lend further support to this proposition. Their crushing workloads have incentivized Chinese judges to close cases as expeditiously as possible, and divorce petitions are easy targets owing in part to the highly discretionary and subjective breakdownism test discussed above. For decades, a shortage of judges has been cited as a rationale for denying divorce petitions (Research Office of the Nanjing Municipal Intermediate Court 1987, p. 16).

A widening imbalance between the supply of and demand for judicial services is widely discussed as the problem of "many cases, few judges" (案多人少). Growth in the population of judges, currently at a little over 200,000 (Jiang 2015, p. 26; Zheng, Ai, and Liu 2017, p. 169), has been far outstripped by growth in the volume of litigation. Between the late 1970s and the early 2010s, court dockets expanded by a factor of 20, while judge positions multiplied by only a factor of between 2 and 3 (Jiang 2015, p. 26).

Even if various policy efforts aimed at better optimizing the use of limited judicial resources succeed, bureaucratic efficiency and capacity improvements in China's courts are not a sufficient condition of-and will not 
automatically translate into - more faithful implementation of China's global and domestic legal commitments. The technical ability to grant a higher proportion of divorce petitions, particularly to plaintiffs claiming domestic abuse, does not imply sufficient motivation on the part of judges to do so.

\section{Political Ideology}

President Xi Jinping is often credited with the biological metaphor of the family as the basic cell of the organism of society. Although he was not the first to use this metaphor (Zhang 1957; Liang 1982; Chen 2005, p. 155; Jiang 2009a, p. 63), he restored and elevated to new heights the political salience of the ideology discussed earlier calling for preserving the family by opposing frivolous divorce.

China's Ministry of Civil Affairs has reportedly "warned of 'irrational divorces' and called for people to have a more responsible attitude towards marriage" (Zhou 2017). "Xi Jinping champions the family as the basic cell of society and the first school in life. No matter what, we must attach importance to building up the family" (Henan Provincial Academy of Social Sciences Research Team 2017, p. 10). A nationwide "domestic relations trial reform" introduced in 2015 became a focus of new policy efforts aimed at preserving and reconciling marriages on the rocks through intensive mediation intervention on the part of social workers, psychologists, and female judges (Henan Provincial Academy of Social Sciences Research Team 2017). Several provinces have even experimented with cooling-off periods for the explicit purpose of controlling rising divorce rates (Zhou 2018, p. 35). In Henan Province, according to one report, under the banner of this reform, "steadfastly "persuading reconciliation and not persuading breaking up,' and establishing 3-6 month 'cooling-off periods' for impulsive divorce cases with reconciliation potential, have helped 22,000 families on the verge of breakdown stay together" (Henan Provincial Academy of Social Sciences Research Team 2017, p. 10). Low fertility rates are an additional impetus not only for rescinding the one-child policy but also for official efforts to limit divorce (Myers and Ryan 2018).

Political ideology is not the only tool shaping judicial decision-making. Ideological signals from above exert direct pressure on judges and are also indirectly mediated by judicial performance evaluation systems.

Judicial Performance Evaluation Systems

Judicial performance evaluation systems, also known as judicial responsibility systems, serve to shape judicial behavior by delivering tangible 
rewards and punishments to judges according to their degree of compliance with prevailing political policies and ideologies. As civil servants without tenure, Chinese judges are highly responsive to incentive structures designed to support shifting political priorities. Their risk-averse practices are captured by the idiom, "Seek not to do good work but rather to avoid blame" (Li and Zhou 2018, p. 64). Their imperative to satisfy the demands of judicial responsibility systems (He 2009; Kinkel and Hurst 2015; Liebman 2015), which are institutional legacies of both imperial China and the Mao era (Minzner 2009), compete with their incentives to uphold China's domestic laws and global legal commitments.

Judges are scored, above all, according to productivity and efficiency measures such as volume of closed cases and average closing times. They are also scored according to social stability measures, including incidents of litigants petitioning due to their dissatisfaction with court decisions (An 2015, p. 179). Nothing will derail the career of a judge faster than an "extreme incident" that inflames public outrage fanned by media exposure. Judges, no different from officials elsewhere in the state apparatus, make discretionary ad hoc material concessions to litigants who pose credible threats of carrying out or inciting a quintessentially "extreme" incident such as petitioning, public protest, suicide, and murder. Judges complain that their courts have been hijacked by litigants who often get what they want by threatening unrest (X. Li 2014, p. 220). The paramount importance of "maintaining social stability" has incentivized aggrieved citizens to threaten unrest while also incentivizing officials responsible for dealing with them to adopt populist strategies for redressing their grievances in arbitrary ways (Lee and Zhang 2013; Liebman 2013, 2014; He 2014, 2017; Feng and He 2018).

In the context of divorce litigation, a plaintiff can sometimes get her way by threatening to commit suicide if her petition is not granted. Meanwhile a defendant who does not consent can sometimes get his way by threatening to murder the plaintiff if her petition is granted. Judges take such threats seriously because they are sometimes carried out; judges have no way of knowing who is bluffing and who will follow through (Wang 2013, p. 84; He 2017). For this reason, social stability considerations compel judges to use the breakdownism test instrumentally and often unlawfully to deny divorce petitions not despite but because of domestic violence and the perceived potential for worse violence if a divorce is granted. One judge persuaded a plaintiff to reconcile with rather than to divorce her abusive husband: "He says he will kill you if you divorce him, and it seems he is serious. We cannot ensure your safety if we render a divorce decision. To tell you the truth, it is rather easy for us to render a divorce judgment. The reason why I bother to talk you into reconciliation is all for your good" (Wang 2013, p. 84).

The routinization of adjudicated denials of first-attempt divorce petitions is well documented (He 2009). In a phenomenon we can think of as the 
"divorce twofer," the routinization of granting divorces on the second attempt is also well documented (Chen 2005; He 2009; He and Ng 2013a; Luo 2016). When a court denies a first-instance divorce petition, the process can be reset following a statutory waiting period of six months. ${ }^{4}$ According to Hongxiang $\mathrm{Li}$ (2014, p. 87), in practice "the breakdown of mutual affection test is based simply on the number of times a divorce has been requested ... which undermines women's freedom of divorce rights." It may seem counterintuitive that the divorce twofer, by multiplying court petitions, could help relieve the crushing pressure of China's court dockets. Even if both sides agree to divorce, judges may be skittish about ruling on contentious property division and child custody claims. By both helping judges to clear cases efficiently and giving litigants additional time to negotiate and agree on the terms of the divorce in preparation for a subsequent attempt, the divorce twofer alleviates judges' workloads, boosts volume and efficiency measures, and reduces the probability of dissatisfaction, petitioning, and extreme incidents. This is precisely why I call it a "twofer": by trying the same case twice, judges can get double credit while minimizing their professional liability. By denying a divorce petition, judges can kick the can down the road for at least six months, and in so doing maximize their professional rewards and minimize their professional risks. "To deny a divorce on the first attempt and grant it on the second attempt is safer and more reliable, and of great help raising a judge's individual performance evaluation scores" (Xiao, Ma, and Tuo 2014, p. 63).

Pressures from three endogenous institutional logics - court capacity constraints, political ideology, and performance evaluations-incentivize judges to deny first-attempt divorce petitions, particularly when they involve claims of domestic violence. Denying a first-attempt divorce petition is a rational strategy for both minimizing the risk of negative fallout and maximizing performance evaluations. The divorce twofer can only be understood as a consequence of norms and practices endogenous to the institutional environment in which China's courts are embedded. Although I have explained why judges routinely deny first-attempt divorce petitions, I have not explained why they might disproportionately deny the firstattempt divorce petitions of women. Routinely denying first-attempt divorce

\footnotetext{
${ }^{4}$ Divorce litigation represents an exception to the general rule - and a defining characteristic of China's court system - known as the "maximum of two decisions" or the "secondinstance trial is always final” (两审终审制). Circumventing the six-month waiting period on the basis of "new developments" or "new reasons" is permitted but happens rarely in practice. Following an adjudicated denial, a subsequent divorce attempt counts as a new first-instance trial. For no other type of litigation is there the option of a first-instance doover. For every other type of case an undesirable outcome can, generally speaking, only be appealed and accepted as a second-instance trial.
} 
petitions is more than a rational strategy adopted by risk-averse, careermaximizing judges. Judges' behavior also adheres to a cultural logic.

\section{Patriarchy}

The impact of the global diffusion of norms and laws promoting gender equality may be stymied by the persistence of countervailing local cultural schemas (Ridgeway 2011). Cultural categories of moral worthiness and deservingness can undermine women's efforts to get justice through the law (Michelson 2006, pp. 6-7; on "cultural categories of worth" more generally, see Steensland 2006). Divorced women in China belong to a stigmatized and socially disgraced cultural category of "outcasts" who are "morally bankrupt" (Honig and Hershatter 1988, pp. 212-13, 224, 237-40; also see Buck 1931, p. 907; and Mo 2017, p. 391). A prevailing trope in Chinese narratives about "frivolous" and "impulsive" divorce is a woman recklessly rushing to divorce her husband only to harbor regrets after cooling off and regaining her composure (e.g., Chang 2017). Allegations of widespread "abuse of the freedom of divorce" are seemingly uniformly supported by anecdotes of "impetuous and capricious" women initiating the litigation process (Tian 2016, p. 25; Ma 2018; also see Honig and Hershatter 1988, pp. 212, 224). Narratives about a selfish generation of only children-born in the 1980s and 1990s after the nationwide implementation of family-planning policies - fueling China's allegedly runaway divorce problem are supported by anecdotes of outrageously trivial arguments leading to female-initiated divorce, such as the wife who filed for divorce after her husband changed the Wi-Fi password and failed to share it with her, and the wife who filed for divorce because her husband failed to tear toilet paper on the perforations (Ma 2018, p. 17).

Judges elsewhere invoke and reproduce shared, taken-for-granted cultural assumptions about gender; they "unjustly discount women's personal trustworthiness" (Epstein and Goodman 2018, p. 405; emphasis in original). Patriarchal cultural beliefs help explain why women seeking help from China's courts bear the brunt of institutional pressures to maximize judicial efficiency. When "efficiency overrides due process," litigation is biased in favor of men. When "efficiency takes priority over due process," judges render decisions mechanically and mindlessly, "without the need to use their brains," and in so doing bring gender stereotypes, implicit bias, and prejudice into play (Lin, $\mathrm{Bu}$, and $\mathrm{Li} 2015$, p. 124). In an institutional context such as this, characterized as having undergone "judicial patriarchialization," judges - the majority of whom are men - take men's claims more seriously than women's and are more likely to grant men's divorce petitions than women's (Lin et al. 2015). Owing to the central role of prejudices and 
preconceptions in judicial decision-making, the trial has been characterized as little more than a formalistic exercise of judges going through the motions to render a predetermined judgment ( $\mathrm{Li}$ and $\mathrm{Ye} 2015$ ). In the context of gender violence elsewhere in the world, stereotypes about women as unstable, unreasonable, emotional, hysterical, overly sensitive, flighty, and irrational undermine their credibility and thereby undermine gender equality in court (Stanko 1982; Frohmann 1991; Goodmark 2005; Epstein and Goodman 2018). Chinese judges are more likely to respond dismissively with impatience and annoyance to female litigants than to male litigants, often by interrupting with a raised voice, interjecting with belittling comments, pointing at them, striking the bench, and ignoring their questions (Chen 2007; $\mathrm{Bu}, \mathrm{Li}$, and Lin 2015).

Chinese judges are on the lookout for litigants who try to game the system through deception. They are suspicious of litigants who, with malicious intent, give false testimony, submit fake evidence, or use other deceptive methods to achieve their divorce goals (Sun 2010; Dong and Ji 2016, p. 89). In particular, judges fear litigants make false claims about both domestic violence and the unknown whereabouts of their spouses. Judges' suspicions about the integrity of litigants are not gender neutral. With respect to domestic violence claims, judges commonly believe, either consciously or implicitly, that women exaggerate or fabricate their claims of marital violence in order to boost their chances of gaining child custody or to vent their frustrations and shame their husbands (He and Ng 2013a; Epstein and Goodman 2018). Because they perceive men's claims as more credible than women's, judges tend to support seemingly homicidal men over seemingly suicidal women (He 2017).

Just as they harbor doubts about domestic violence claims, judges can also be wary of claims of missing defendants. Plaintiffs, either on their own in opposition to their spouses or in cahoots with their spouses, may conceal from the court the whereabouts of their spouses and falsely claim they have tried unsuccessfully to make contact. In efforts to surmount obstructionism from a defendant who does not consent to divorce, and to deprive a defendant of marital property and child custody, a plaintiff may surreptitiously divorce under the false pretense of the defendant's unknown whereabouts (Tao and Lu 2012, p. 66). It is often the plaintiff alone who orchestrates the exploitation of the public notice service of process system in this way. Married couples, however, may also be motivated by the shared benefits of a "fake divorce" discussed earlier and hatch a plot jointly to deceive judges (Tan and Wang 2011, p. 116). In either case, litigants may provide fake addresses as decoys, give false testimony, arrange witnesses and coach them to lie, or falsify affidavits from villagers' committees. Not surprisingly, scholars have characterized the public notice method of serving defendants as a 
"legal fiction" (Zhao 2018) grounded in "deliberate fabrication" (Dong and Ji 2016, p. 89). To the extent that judges' vigilance to combat litigation fraud and their skepticism of the veracity of plaintiffs' claims vary according to the gender of the plaintiff, we might expect judges to be warier of female plaintiffs and to give male plaintiffs greater benefit of the doubt.

Given the absence of defendants to challenge plaintiffs' claims, in absentia trials are less contentious and less complicated and can therefore help judges clear their cases. For this reason, judges have an incentive to look the other way when plaintiffs claim not to know the whereabouts of their spouses. Scholars characterize judges' lax scrutiny of claims of missing spouses as judicial misuse and even abuse of the public notice method of serving defendants (Sun 2010; Wang 2012, p. 120). The same lax evidentiary standards that make them convenient to judges also invite their abuse - or at least the perception of their abuse- by litigants. We will see that judges' willingness to look the other way varies according to the gender of the plaintiff.

One of China's oldest and most popular reality shows, Legal Report (今日说法), nationally broadcast daily on China Central Television, includes an illustrative episode about an unhappily married woman who disappeared without a trace. More than six years later, her husband learned she had married another man in a different city. In order to do so without committing the crime of bigamy, she had first obtained a public notice divorce from a court in the jurisdiction of her natal family by falsely claiming, with the support of fake evidence, that she and the original husband established their marital residence in her natal village, and that, as a migrant worker, he subsequently went missing (Zeng 2008, p. 161). The surprise of discovering that one is no longer married-precisely what happened to the husband in this case-has entered the popular vernacular as "unwittingly divorced" (被离婚; Wang 2012; Zhao 2018).

To be sure, stories of male plaintiffs committing this sort of fraud are also in circulation, including the sensational case of billionaire Du Shuanghua whose wife filed for divorce a decade after he had already obtained a court divorce without her knowledge (Liu 2011; for additional examples of women who became unwittingly divorced, see Sun [2006, pp. 122-23] and Xu [2007, p. 204]). However, the well-known narrative of falsely claiming a defendant missing, sometimes with the support of fake evidence, in order to mislead the court into improperly using a public notice with the goal of acquiring most or the entirety of the marital estate, winning child custody, or expeditiously marrying a lover (Tan and Wang 2011, p. 116; Wang 2012, p. 120), arguably carries greater cultural resonance when the plaintiff is a woman. Indeed, cultural stereotypes about duplicitous, wily, conniving women on the make and their ulterior motives to gain unfair advantage in property division and child custody undermine female litigants in U.S. divorce trials (Epstein and Goodman 2018). 
When defendants are falsely purported to be missing, they are easily deprived of their civil litigation rights and marital rights (Dong and Ji 2016, pp. 89-90; Xu 2007, p. 204; Zhao 2018). However, just as female plaintiffs may be deemed less deserving of divorce than male plaintiffs, female defendants too may be deemed less deserving than male defendants of legal protections and procedural rights. Defendants may purposely conceal their own whereabouts in order to evade being served notice because they are already living with a new partner and hope to avoid criminal culpability and civil liability for unlawful cohabitation or bigamy (Ningbo City Yinzhou District People's Court 2014, p. 17). Owing to patriarchal cultural beliefs, this possibility may strike judges as more plausible when the allegedly missing defendant is a woman. In short, male plaintiffs may accrue advantage over otherwise similar female plaintiffs because women are given short shrift as both plaintiffs and as defendants.

\section{HYPOTHESES}

From the foregoing, I derive hypotheses about competing legal standards on judges' decisions to grant and deny divorce petitions. I divide my hypotheses into two sets. First are hypotheses concerning faultism and breakdownism. The second set of hypotheses concerns variation by gender.

\section{Hypotheses concerning Faultism and Breakdownism}

As we saw, China's legal standards for unilateral divorce include provisions consistent with global legal norms that allow and even oblige courts to support unilateral divorce requests from plaintiffs claiming to be victims of domestic violence. We also saw that the "breakdown of mutual affection" is a competing and highly subjective endogenous legal standard that Chinese judges often apply according to mutual consent and the lack thereof. In practice, the breakdownism test conveniently justifies judges' imperative to deny divorce petitions on the basis of the endogenous institutional logics of clogged courts, a political ideology hostile to divorce, and performance evaluation systems that reward judges for volume and efficiency and punish judges for social unrest and "extreme incidents." The logic of the breakdownism divorce test is its flexible and discretionary application for the purpose of supporting the political goals of family preservation and social stability. Indeed, according to the deputy chair of the committee responsible for the 1980 Marriage Law, this was precisely the legislative intent of breakdownism, which "at once maintains the principle of freedom of marriage and also gives the courts considerable latitude" (Huang 2005, p. 187). How seriously Chinese judges treat domestic violence claims in divorce litigation depends on the relative importance of faultism and breakdownism tests. 
American Journal of Sociology

Two inverse hypotheses address the question, Are domestic violence claims (faultism) more or less likely than defendant consent (breakdownism) to result in an adjudicated divorce on the first attempt?

Нyротнеsis 1a.-According to the logic of China's legal standards for unilateral divorce, domestic violence claims are more important than defendant consent.

Hypothesis 1b.-According to the logic of China's breakdownism divorce standard, defendant consent is more important than domestic violence claims.

Two inverse hypotheses address the question, Do domestic violence claims (faultism) increase or decrease the probability of an adjudicated divorce?

Нypothesis 2a.-According to the logic of China's fault-based legal standards for unilateral divorce, domestic violence claims increase the probability of an adjudicated divorce on the first attempt.

Hypothesis 2b.-According to the logic of China's breakdownism divorce standard, domestic violence claims either have no effect on or reduce the probability of an adjudicated divorce on the first attempt.

\section{Hypotheses concerning Gender}

If gender stereotypes reflecting and undergirding patriarchy influence divorce litigation outcomes, we should expect to find that female plaintiffs have borne the brunt of China's clampdown on adjudicated divorce.

Нyротнеsis 3.-All else equal, female plaintiffs are less likely than male plaintiffs to win their freedom in court on the first attempt.

Hypothesis 3 predicts an overall effect of plaintiff sex. We should also expect that gender effects are conditional on faultism and breakdownism. To the extent that judges are more likely to downplay or "normalize spousal abuse" claims (Li 2015b) if they are made by female plaintiffs, a positive effect of a domestic violence claim should be smaller for female plaintiffs and a negative effect of a domestic violence claim should be greater for female plaintiffs.

Hypothesis 4a.-If hypothesis 2 a finds support, a domestic violence claim increases the probability of divorce on the first attempt for male plaintiffs more than for female plaintiffs.

Hypothesis 4b.-If hypothesis $2 b$ finds support, a domestic violence claim reduces the probability of divorce on the first attempt for female plaintiffs more than for male plaintiffs.

If, as stated by hypotheses $4 \mathrm{a}$ and $4 \mathrm{~b}$, we expect domestic violence claims (to the extent that they make any difference at all) to help men more than women - or to hurt women more than men-in their efforts to divorce, we should likewise expect in absentia trials to help men more than women. 
If judges are more suspicious of women's claims of domestic violence, they should likewise be more suspicious of women's claims of missing and incommunicado spouses and should consequently be more reluctant to grant divorces to women in public notice trials. Similarly, if judges deem male defendants to be more deserving than female defendants of legal protections and due process, they should be more reluctant to grant divorces to women when their husbands fail to defend themselves in court than they are to grant divorces to men when their wives fail to defend themselves in court.

Нуротнеsis 5.-When the defendant is in absentia, regardless of whether the defendant is served directly or by public notice, judges are more likely to grant divorces to male plaintiffs than to female plaintiffs on the first attempt.

When defendants consent to divorce, judges may feel relatively empowered to grant first-attempt petitions on the grounds that mutual consent is tantamount to the breakdown of mutual affection and because the Marriage Law calls for granting divorces to husbands and wives who both desire it (Article 31). At the same time, judges may be more likely to regard divorce petitions as "frivolous," "rash," or "deliberately fabricated" when filed by women than when filed by men. If true, female plaintiffs benefit less than their male counterparts from mutual consent.

Hypothesis 6.-When defendants consent to divorce, judges are more likely to grant divorces to male plaintiffs than to female plaintiffs on the first attempt.

According to hypotheses 4-6, women are disadvantaged by judges' wide discretion and latitude in the process of weighing the credibility of plaintiffs against the deservingness of defendants. By contrast, when defendants withhold their consent to divorce, the sheer strength of the breakdownism standard compelling judges to deny first-attempt divorce petitions may leave little room for them to privilege male litigants. When a defendant is unwilling to divorce, a first-attempt divorce petition is often a nonstarter for judges. We might therefore expect that a divorce granted on the first attempt in the absence of mutual consent is similarly improbable for female and male plaintiffs alike.

Hуротнеsis 7.-Regardless of the plaintiff's sex, judges are uniformly unlikely to grant a divorce on the first attempt when the defendant withholds consent.

\section{DATA AND METHODS}

As part of broader government transparency initiatives, selected Chinese courts began publishing their decisions on public websites on a trial basis in the early 2000s, but in significant numbers beginning only in 2008 (Tang and Liu 2019; Ma, Yu, and He 2016). Prior to the promulgation of SPC rules in 2013 requiring all courts to publish (almost) all their decisions on the 
SPC's newly launched website, China Judgments Online (located at http:// wenshu.court.gov.cn/), provincial high courts regulated the online posting of decisions on their own websites under the guidance of the SPC (Hou and Keith 2012; Liebman et al. 2017; Ahl and Sprick 2018). Some high courts, including those in Henan and Zhejiang, maintained their online repositories of court decisions even after the SPC mandated the transition to its centralized website.

I chose Henan and Zhejiang for several reasons. First, they are among the earliest and most prolific publishers of court decisions. Second, their provincial high court websites, unlike China Judgments Online, were highly amenable to automated mass downloading of documents. Third, Henan and Zhejiang are large provinces that capture some of China's regional and socioeconomic diversity. An argument about the strength and impact of endogenous institutional norms would be less convincing if supported by findings from a single province. A high degree of empirical consistency between subnational units that otherwise differ would lend stronger support to my claims.

In the remainder of this section I provide some general background information on the two provinces represented in this study, assess the representativeness of the court decisions in my samples, detail my methods of constructing the measures in my analyses, and describe my plan of analysis.

\section{Henan and Zhejiang}

Reflecting their large sizes and locations in China's poorer agricultural heartland and its more prosperous coastal Yangtze River Delta, respectively, Henan and Zhejiang taken together accounted for $11 \%$ of the national population in 2016 and represent a wide geographical and socioeconomic swath of the country. With crude divorce rates slightly below the national average (2.9 in Henan and 2.6 in Zhejiang compared with the national rate of 3.0 per 1,000 population), both provinces in 2016 together accounted for $10 \%$ of all divorces and $10 \%$ of all divorces granted specifically by court adjudication (Ministry of Civil Affairs of China, various years). In 2016, with a population of 95 million, Henan was the third most populous province behind Guangdong (110 million) and Shandong (99 million). Zhejiang's population of 56 million ranked it tenth in the country out of all 31 provinces, autonomous regions, and centrally administered municipalities. In terms of per capita GDP, Henan (ranked 20th) was 25\% lower-and Zhejiang (ranked fifth) $50 \%$ higher - than China as a whole. Similarly, in terms of urbanization, the share of Henan's population residing in urban areas (ranked 25th) was 9 percentage points below - and Zhejiang's (ranked seventh) 9 percentage points above - the national average of $56 \%$. Reflecting the relative importance of agriculture in each province, the primary sector accounted for $11 \%$ of Henan's GDP but only 4\% of Zhejiang's in 2016. Henan is a net exporter 
of internal migrants, whereas Zhejiang is a net importer of internal migrants (many hailing from Henan; Liu et al. 2014). In terms of the total value of international trade in 2016, Zhejiang ranked fourth behind Guangdong, Jiangsu, and Shanghai, whereas Henan ranked tenth (with imports and exports valued at only one-fifth of Zhejiang's). ${ }^{5}$

Although judges are a male-dominated profession in both provinces, women were better represented on the bench in Zhejiang (about one-third) than in Henan (about one-quarter) in 2013 (Henan Provincial Bureau of Statistics, various years; Zheng et al. 2017, p. 181). In 2015, Zhejiang was ranked first among all provinces and centrally administered cities in terms of judges' average caseload. Zhejiang's average caseload of 218 closed cases per judge was 2.2 times the national average and perhaps three times heavier than Henan's (Henan Provincial Bureau of Statistics, various years; Liu 2016; Yu and Meng 2016).

\section{The Samples}

The court decisions analyzed in this article were downloaded in bulk from the websites of the Henan and Zhejiang provincial high courts: http://oldws. hncourt.gov.cn/ and http://www.zjsfgkw.cn/Document/JudgmentBook, respectively. ${ }^{6}$ Because the vast majority of decisions published online were made after 2008, and because all courts in China were required to stop posting divorce decisions online in October 2016, I limit all analyses of Henan's decisions to 2009-15 ( $n=74,654)$ and of Zhejiang's decisions to 2009-16 ( $n=$ 73,720).

Table 1 affirms that online collections of court decisions are well suited for the study of adjudicated divorce outcomes. Looking at all years covered by the samples, online divorce adjudications account for $60 \%$ and $46 \%$ of the true population of divorce adjudications in Henan and Zhejiang, respectively. Excluding years when courts uploaded relatively few decisions, online divorce adjudications as a proportion of all divorce adjudications are $75 \%$ in Henan (2011-14) and 70\% in Zhejiang (2010, 2014-16). With the exception of special courts (railway transportation courts and maritime courts), my samples include cases from every basic-level court in each province: 161 in Henan and 91 in Zhejiang.

\footnotetext{
${ }^{5}$ All uncited figures and rankings in this paragraph come from the National Bureau of Statistics (http://data.stats.gov.cn).

${ }^{6}$ The URLs of the decisions were http://oldws.hncourt.gov.cn/paperview.php?id=[deci sion ID\#] and http://www.zjsfgkw.cn/document/JudgmentDetail/[decision ID\#], for Henan and Zhejiang, respectively, where "[decision ID\#]" refers to a unique numerical identifier. I am grateful to Alice Wang for downloading the Henan decisions before they were taken offline in January 2018. The website has since been restored, but without the vast majority of the originally available decisions. Zhejiang's decisions were taken offline sometime in the middle of 2019.
} 


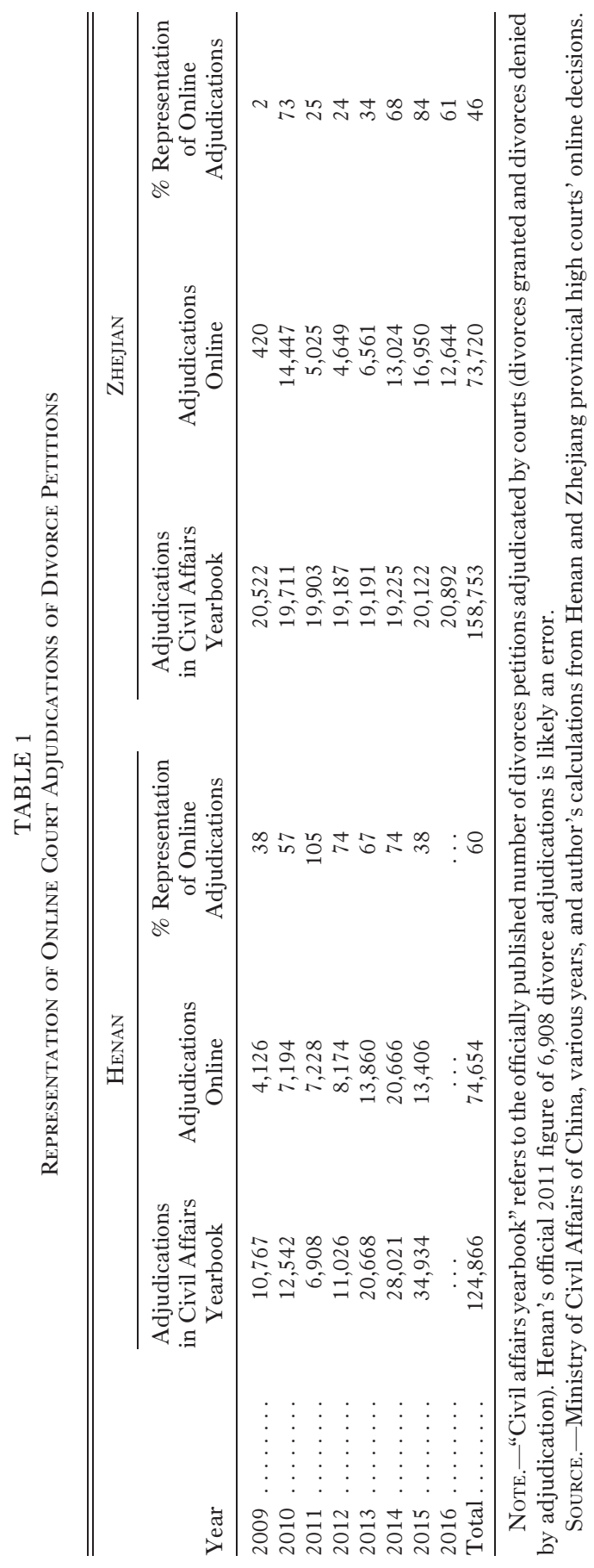

This content downloaded from 140.182.176.013 on August 01, 2020 19:45:19 PM All use subject to University of Chicago Press Terms and Conditions (http://www.journals.uchicago.edu/t-and-c). 
Quantitative analyses in this article are limited to adjudicated judgments of first-attempt divorce petitions ( $n=57,752$ from Henan and $n=51,614$ from Zhejiang) for three reasons. First, the heart of the matter lies with first-attempt petitions. As we will see, most first-attempt divorce requests are denied and most subsequent requests are granted. Second, routine denials of first-attempt divorce requests often force women to stay with or hide from abusive spouses. Insofar as delays to divorce caused by routine denials are typically about one year in duration and are experienced disproportionately by women (as we will see), they exacerbate economic and emotional hardships suffered disproportionately by women seeking their freedom, many of whom are victims of marital abuse. Third, court rulings on subsequent divorce petitions are right censored; we have no way of knowing who returns to court after how long a period of time following an adjudicated denial. Published court decisions are therefore of questionable suitability for the analysis of what happens to people after their first-attempt divorce petitions are denied.

\section{Measures}

The technical challenges posed by the task of rendering text into quantitative data were multiplied by the sheer volume of text. The main sections of text in the 148,374 court decisions in my two samples consist of over 200 million Chinese characters, Latin letters, and Arabic numerals (95 million and 107 million in the Henan and Zhejiang samples, respectively). Although hand coding even a fraction of this much text would be hopelessly infeasible, the machine-coding process nonetheless requires a great deal of manual reading in order to develop appropriate text parsing techniques and to refine them incrementally and iteratively through random audits - searching for errors by comparing machine codes with the original text from which they were derived. I hand-coded random samples and assessed the degree of consistency between the manual codes with the machine codes. Imperfection notwithstanding, they are highly accurate, reliable, and valid. Among 400 decisions randomly selected from both samples, levels of agreement between hand codes and machine codes on all measures range from $94 \%$ to $100 \%$. $^{7}$

\section{Core Variables}

The variables I describe in this section include a flag variable that limits the scope of the analysis to first-attempt divorces petitions, the dependent

\footnotetext{
${ }^{7}$ Among my measures, Cohen's kappa of interrater reliability ranges from .88 to 1.00 . Values of Cohen's kappa above .80 are considered "almost perfect" (Landis and Koch 1977 , p. 165; McHugh 2012, p. 279).
} 
variable (the court ruling to grant or deny the petition), and the three key theoretical variables I use to test my hypotheses: domestic violence (faultism), defendant consent (breakdownism), and plaintiff sex.

First-attempt divorce.-Courts almost always cite in their decisions case IDs of prior decisions pertaining to the dispute in question. I therefore coded as a subsequent-attempt divorce petition any first-instance divorce decision containing a reference to a previous civil case - either a specific civil case ID or a descriptive reference to a previous divorce litigation attempt. Descriptive references come from a wide array of words and phrases (曾向本院起诉, 再次提出离婚, 再次诉至法院, 原告于[previous date]起诉要求离婚, and many additional variants). I coded all remaining first-instance divorce decisions as first attempts.

Grant or deny the divorce petition.-Within relevant sections of text, adjudicated denials can be reliably identified by words and phrases such as “deny” (不予支持 or 不予准许), “do not approve”(不准), and “reject” (驳回). Adjudicated approvals of divorce petitions can be identified by words and phrases such as “approve” (准予 and 准许) and “dissolve” (解除) that do not satisfy the criteria for adjudicated denials.

Domestic violence.--Similar to Luo's (2016, p. 15n3) approach, I did not limit the definition of "domestic violence" to claims expressed by plaintiffs using this specific term (家庭暴力). I included a variety of additional, often colloquial, terms and phrases for physical and verbal abuse commonly used by plaintiffs (e.g., 家暴, 打骂, 打伤, 殴打, 动手, 毒打, 大打出手, 拳打脚踢, and 拳脚相加).

Defendant consent.-I defined a defendant's unwillingness to divorce using phrases such as "oppose," "disagree" with, or "object" to the divorce (不同意离婚, 不同意与原告离婚, 不同意解除, 不愿与原告离婚, 不想与原告离婚, and similar variants), "I request that the court reject the plaintiff's petition" (请求法院驳回, 请驳回, 希望法庭驳回, and similar variants), “I hope to reconcile with the plaintiff” (variants of 希望能和原告和好), and other relevant words and phrases. Defendants can only express consent or withhold consent if they participate in the litigation process, usually in person, in writing, or by proxy but occasionally by telephone. In order to assess the effect of consent, therefore, this variable also includes values for a defendant's failure to participate in court proceedings. I defined the absence of defendant participation using phrases such as “failed to appear in court" (未到庭), “failed to provide a defense" (未做答辩), “failed to submit a defense statement” (未提交答辩状), “in absentia trial” (缺席审理), “refused to appear in court without due cause after being served a court summons" (经本院传票 传唤无正当理由拒不到庭), and other relevant variants. The presence of the word "public notice" (公告) differentiates in absentia public notice trials in which defendants were alleged to be missing from other in absentia trials in which defendants were served by regular means because they were not 
alleged to be missing. By including in absentia defendants in this measure of defendant consent, we can be confident that the value of "defendant consented to divorce" captures a documented expression of affirmative consent and therefore excludes a failure to withhold consent owing to failure to participate in court proceedings.

Plaintiff sex.-Personal details about litigants - including name, sex, date of birth, officially registered residential address, and nationality - are disclosed in the vast majority of decisions in the Henan sample: $94 \%$ of all decisions on first-attempt petitions include litigant sex $(54,536$ out of 57,752 ). In the Zhejiang sample, by contrast, only $3 \%$ of first-attempt decisions disclosed litigant sex $(1,536$ out of 51,614$)$. Courts in Zhejiang took great care to redact the personal identifying information of litigants and their family members. The redaction of litigant names precludes gender guessing on the basis of given names (typically only surnames are retained).

However, I was able to infer litigant sex (both plaintiffs and defendants) from almost 7,000 additional first-attempt decisions (and from more than 2,000 additional subsequent-attempt decisions) with a high degree of accuracy according to the content of text about three gendered topics: (1) bride price (彩礼), (2) dowry (嫁妆), and (3) wives' natal families (娘家). Because the bride price is paid by the husband's family, a litigant's statement concerning the plaintiff's payment of bride price or the plaintiff's request for the return of the bride price is a valid and reliable indication that the plaintiff is male. Because the dowry is paid by the wife's family, language in a court decision claiming or affirming the plaintiff's payment of the dowry or the plaintiff's request for its return is a valid and reliable indication that the plaintiff is female. Likewise, a statement concerning the plaintiff's receipt of - or obligation to return - the bride price or dowry indicates that the plaintiff is female or male, respectively. Finally, a litigant's statement concerning the plaintiff's return to "the wife's natal family" is a valid and reliable indication that the plaintiff is female. ${ }^{8}$

I assessed the reliability of this method of inferring litigant sex by comparing inferred sex with disclosed sex. The level of agreement between the two values of sex among the 474 litigants in the Zhejiang sample with both was $97 \%$ (Cohen's kappa $=.95$ ). Applying the same method of inferring sex to the Henan sample is a far better test of its accuracy. Thanks to its high rate of litigant sex disclosure, the Henan sample is an ideal source of "training data" for machine coding litigant sex. The level of agreement between the two values of sex among the 27,434 litigants in the Henan sample with both was $96 \%$ (Cohen's kappa = .91). Plaintiff sex in my Henan sample

${ }^{8}$ When a plaintiff's sex was inferred using these rules, the defendant was assigned the opposite sex. Of course I applied the same rules to defendants. Thus, when a defendant's sex was inferred using these rules, the plaintiff was assigned the opposite sex. 
( $n=54,200$ ) comes exclusively from the published court decision because I would have gained only an additional 570 court decisions (1\%) by inferring litigant sex in decisions that did not originally disclose it. Of all values of plaintiff sex in my Zhejiang sample $(n=8,626), 83 \%$ were inferred.

\section{Control Variables}

Control variables are essential in order to minimize the possibility that an observed effect is an artifact of an omitted correlate. In order to assess the effects of theoretical variables among otherwise similar cases, I control for the year of the decision, whether or not the plaintiff submitted evidence, whether or not the plaintiff gave up marital property or child custody, a physical separation claim, the participation of one or more female judges, the civil procedure adopted (ordinary or simplified), marital duration, marital property, children, and the participation of legal counsel. The online appendix contains details about the operational definitions of all control variables, descriptive statistics of all variables, and full regression results.

\section{Analytical Strategy}

I use average marginal effects (AMEs) to assess the impact of plaintiff sex, domestic violence (faultism), and defendant consent (breakdownism) on courts' granting adjudicated divorces, net of control variables included in the models. An AME can be interpreted as the effect of a variable (say, of changing the value of plaintiff sex from male to female) on the probability the outcome of interest occurs, holding all remaining variables at observed values (Long and Freese 2014, pp. 242-46; Mize 2019, pp. 85-87). ${ }^{9}$ A marginal effect - also known as a first difference - is the difference between the predicted probabilities for each group. An AME is the average of all marginal effects computed for each observation in the sample. The difference between two AMEs is known as a second difference.

I proceed in two steps. First, I present overall AMEs for plaintiff sex, domestic violence (faultism), and defendant consent (breakdownism). Comparing the magnitudes of these effects allows me to test hypotheses 1-3. Second, I present AMEs for domestic violence (faultism) and defendant consent (breakdownism) that vary by plaintiff sex. Comparing the effects of domestic violence by plaintiff sex allows me to test the interaction in hypothesis 4 . Likewise, comparing the effects of defendant consent by plaintiff sex allows me to test the interactions in hypotheses $5-7$.

\footnotetext{
${ }^{9}$ Marginal effects at the mean are calculated while holding all remaining variables at sample means. AMEs are generally the preferred choice (Long and Freese 2014, pp. 245-46; Mize 2019). I replicated all analyses using both methods; results are highly robust.
} 
Regression models presented in this article include interactions between plaintiff sex and the other two theoretical variables, namely, domestic violence and defendant consent. They also include interactions between plaintiff sex and all control variables. For the sake of presentational parsimony, I omit control variables from tables of regression results; I limit the presentation and discussion of regression results to theoretical variables at the heart of my hypotheses.

In regression models for categorical outcomes, group differences cannot be reliably assessed by testing the statistical significance of the coefficients of interaction terms (Allison 1999; Long and Mustillo 2018). Current disciplinary best practices call instead for testing interaction effects - that is, testing differences between groups in the effect of a covariate on the probability of experiencing a given outcome-by testing whether first differences (one for each group) are equal (Long and Mustillo 2018; Mize 2019). I test the interaction effects in hypotheses 4-7 by testing the equality of AMEs (i.e., by testing whether second differences are statistically significant; Long and Freese 2014, p. 285).

I include fixed effects for the court that adjudicated the case in order to account for unobserved heterogeneity across contexts. Because basic-level court jurisdictions correspond to rural counties and urban districts, court fixed effects (court dummy variables) serve the function of controlling for unobserved characteristics of both courts and the contexts in which they are embedded. Court locations also reflect and therefore control for the social origins of divorce litigants. Divorce litigants who hail from rural areas are overwhelmingly at the mercy of rural courts. Rarely do migrants from rural areas file their divorces in urban courts. The court decisions in my samples bear out Li's (2015a, p. 98) assertion that "due to jurisdictional restrictions, rural women who serve as migrant workers in cities and towns must return to their hometowns to file divorce petitions."

\section{DESCRIPTIVE FINDINGS}

Judges used the word "mutual affection" (感情) in their holdings (i.e., their legal reasoning, their explanations of how they arrived at their decisions) in $94 \%$ of all first-attempt decisions in each sample. Ultimately, and consistent with hypothesis $1 \mathrm{~b}$, the breakdown of mutual affection is the standard that mattered most to judges. The following represents tens of thousands of court decisions in my samples containing nearly identical language: " $\mathrm{Mu}$ tual affection is the foundation of marriage, and the statutory standard by which the People's Court grants and denies divorces is whether or not mutual affection has truly broken down" (Decision 939023, Xingyang Municipal People's Court, Henan Province, January 13, 2013). Some judges even proclaimed in their holdings that breakdownism is the only relevant legal test: 
"The court holds that whether or not mutual affection between husband and wife has completely broken down is the sole standard by which to weigh the decision to grant or deny a divorce" (Decision 2393036, Zhuji Municipal People's Court, Zhejiang Province, October 14, 2011).

Rarely did judges refer to fault-based standards of wrongdoing. As we saw in the vignette that opened this article, judges even denied divorce petitions after affirming the occurrence of domestic violence. Judges' used terms such as “violence” (暴力), “bad habit” (恶习), “fault” (过错), and “Article 46" (“四十六” or “46," the provision in the Marriage Law on civil damages for wrongdoing) in their holdings in only $4 \%$ of the published decisions in each of the two samples. Meanwhile, judges invoked political discourse of “stability” (稳定), “civilized” (文明), and “harmonious” (和谐 and 和睦) in $25 \%$ and $13 \%$ of holdings in my Henan and Zhejiang samples, respectively.

China's breakdownism divorce standard, applied by judges in support of the national political priority of preserving marriages, overwhelmingly trumps other circumstances, including marital violence, that, strictly according to China's domestic laws and international commitments, could fully support judges' decisions to dissolve marriages. The breakdownism test enables judges' routine denial of first-attempt divorce petitions. Table 2 shows that judges denied the majority of divorce petitions on the first attempt but granted the majority of subsequent divorce petitions. Some plaintiffs required three or four attempts before judges finally granted their divorce petitions.

Because they are so routinely denied, first-attempt divorce petitions are more consequential than subsequent attempts. When China's multiple legal divorce standards clash and breakdownism prevails over wrongdoing, battered women are often subjected to further violence or forced into hiding. Courts' routine denial of first-attempt divorce petitions, therefore, fuels the expansion of a population of frustrated and often vulnerable plaintiffs seeking and awaiting divorce. The written decisions show that abuse victims who return to court after the statutory six-month waiting period following an

TABLE 2

Divorce Petitions Granted and Denied, by Attempt

\begin{tabular}{|c|c|c|c|c|c|c|}
\hline & \multicolumn{3}{|c|}{ Henan } & \multicolumn{3}{|c|}{ ZHEJIANG } \\
\hline & $\begin{array}{c}\text { First } \\
\text { Attempts }\end{array}$ & $\begin{array}{c}\text { Subsequent } \\
\text { Attempts }\end{array}$ & Total & $\begin{array}{c}\text { First } \\
\text { Attempts }\end{array}$ & $\begin{array}{c}\text { Subsequent } \\
\text { Attempts }\end{array}$ & Total \\
\hline$\%$ divorces granted & 36.6 & 77.4 & 45.9 & 20.0 & 69.4 & 34.8 \\
\hline$\%$ divorces denied & 63.4 & 22.6 & 54.1 & 80.0 & 30.6 & 65.2 \\
\hline Total .......... & 100.0 & 100.0 & 100.0 & 100.0 & 100.0 & 100.0 \\
\hline$n \ldots \ldots$ & 57,752 & 16,902 & 74,654 & 51,614 & 22,106 & 73,720 \\
\hline
\end{tabular}

SourcE.-Author's calculations from Henan and Zhejiang provincial high courts' online decisions. 
adjudicated denial often claim worsening violence (also see Xu 2007, p. 204). For this reason, first-attempt divorce petitions, far more than subsequent divorce attempts, are where the rubber meets the road. One plaintiff indicated the following in her statement: "After I gave birth to my second daughter, the defendant's cruelty towards me intensified. Oftentimes, upon returning home after being out all day, the defendant would beat and curse me. In order to escape this torture, I filed for divorce. The Minquan County People's Court denied my petition in its [prior case ID] decision. I then fled with my older daughter and begged for food in order to survive" (Decision 422754, Minquan County People's Court, Henan Province, July 20, 2010). In this case, the duration of the first attempt (from case filing to adjudicated denial) was 50 days, but the total duration of time between original first-attempt case filing and adjudicated divorce was 2,492 days (almost seven years).

Another plaintiff stated to the court, "In the time since suffering a beating by the defendant in 2007, I have been in hiding, afraid to return home, for over three years. In early 2010 my divorce petition was denied by the Song County People's Court, after which I have still not dared to return home" (Decision 562570, Song County People's Court, Henan Province, April 1, 2011). The duration of the litigation process was over one year, but the overall process lasted three or four years. I could fill hundreds of pages with similarly poignant examples of the grave physical security and public health implications of courts' routine denial of first-attempt divorce petitions.

As courts stepped up their suppression of divorces on the first attempt, the population of divorce seekers awaiting relief has only grown. The duration of time from when the first-attempt petition was filed to when the divorce was ultimately granted on a subsequent attempt can be calculated in two ways: (1) by searching for first-attempt filing dates in the text of subsequentattempt decisions and (2) by linking first-attempt and subsequent-attempt court decisions. In so doing we learn that, among divorces granted on the first attempt, median time to adjudicated divorce was 80 days and 42 days in the Henan and Zhejiang samples, respectively. When the divorce was granted on a subsequent attempt, median time was 422 days and 373 days in the Henan and Zhejiang samples, respectively. Thus, the median delay to freedom caused by a first-attempt adjudicated denial was 342 days and 331 days in the Henan and Zhejiang samples, respectively. ${ }^{10}$

If courts are more likely to deny first-attempt divorce petitions filed by women, and if female plaintiffs are more likely than male plaintiffs to be

${ }^{10}$ Median durations of time to adjudicated divorce were calculated from dates reported in 44,278 and 62,059 first- and subsequent-attempt decisions in the Henan and Zhejiang samples, respectively. Time to divorce is shorter in Zhejiang's courts due to their far more common use of the simplified civil procedure. Calculating median time to adjudicated divorce separately for each type of civil procedure shrinks the differences between the two samples. 
victims of domestic violence, then it can only be true that the delay to freedom is longer for women than for men, and that a nontrivial number of women awaiting their freedom are marital-violence refugees. Even if women who return to court for another attempt are guaranteed a divorce, the tangible and intangible costs to vulnerable abuse victims of a median delay of nearly one year are in some instances incalculable. ${ }^{11}$ Collateral costs may aggravate suffering. Divorce litigation is about more than domestic violence. When courts deny divorce petitions, they also deny child custody and property division claims. Courts often do more to prolong than to redress suffering.

We can see in figure 1 that the clampdown on adjudicated divorce began in the early to mid-2000s and, at least in the case of Henan, intensified after 2011 for reasons discussed earlier, namely, a dramatic increase in the volume of civil litigation and the rising prominence of political discourse concerning marital stability, household harmony, and civilized families. Figure 1 also lends further confidence to the representativeness of my two provincial samples. Figure 1B shows that granted divorces as a proportion of all adjudicated divorce petitions in the three years spanning 2013 and 2015 in my Henan sample $(41.0 \%)$ perfectly mirrors the proportion of granted divorces in the true population of divorce adjudications reported by the Ministry of Civil Affairs $(41.4 \%)$. Likewise, figure $1 \mathrm{C}$ shows that the proportion of adjudicated divorce petitions approved by courts in the three years spanning 2014 and 2016 in my Zhejiang sample $(35.6 \%)$ is close to the approval rate in official sources $(36.9 \%)$.

For comparability purposes, figure 1 is limited to adjudicated outcomes. Had I used official government data to depict all granted divorces (divorces granted by adjudication plus divorces granted by mediation) as a proportion of all divorce petitions submitted to courts (including those subsequently withdrawn by plaintiffs), the same downward trend would have emerged. ${ }^{12}$ Between 2004 and 2016, the proportion of all divorce petitions received by courts resulting in granted divorces fell from $63 \%$ to $49 \%$ in China as a whole,

\footnotetext{
${ }^{11}$ After the first attempt, courts in my samples were actually more likely to grant adjudicated divorces to female plaintiffs than to male plaintiffs. Among subsequent-attempt decisions, the probabilities of adjudicated divorces granted to female and male plaintiffs, respectively, were .82 and $.68(n=13,743)$ in Henan and .77 and $.73(n=3,447)$ in Zhejiang (gender differences in both samples are statistically significant). However, the right-censored nature of the court decisions (plaintiffs may or may not return to court after the end of the period of observation) problematizes any effort to interpret the meaning and significance of women's apparent advantage on a subsequent attempt following a first-attempt adjudicated denial. Published court decisions are poorly suited for the systematic analysis of what happens to litigants after first-attempt adjudicated denials.

${ }^{12}$ Owing to a systematic underrepresentation of mediations and withdrawals in online collections of Chinese court decisions, online court decisions are suitable for studying $a d$ judicated outcomes only.
} 
A. Official Government Statistics

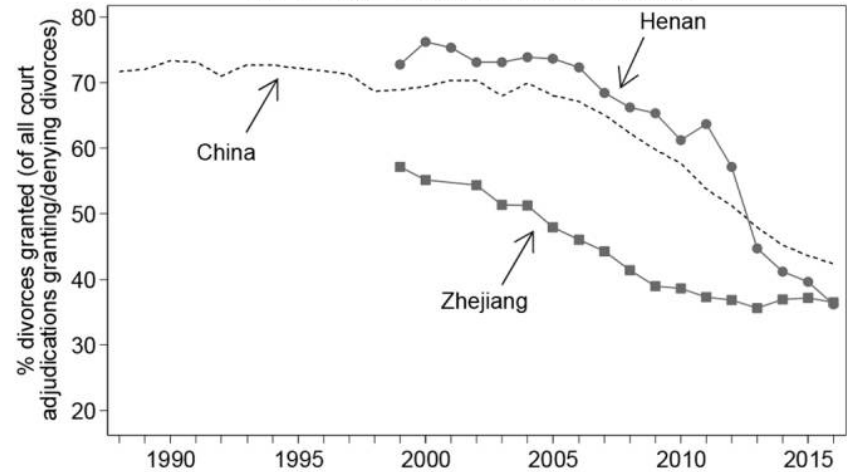

B. Henan: Online Decisions vs. Official Statistics

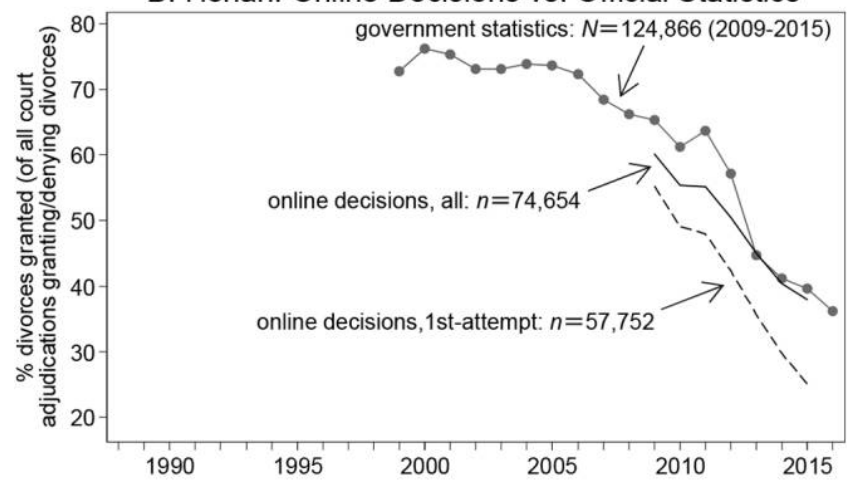

C. Zhejiang: Online Decisions vs. Official Statistics

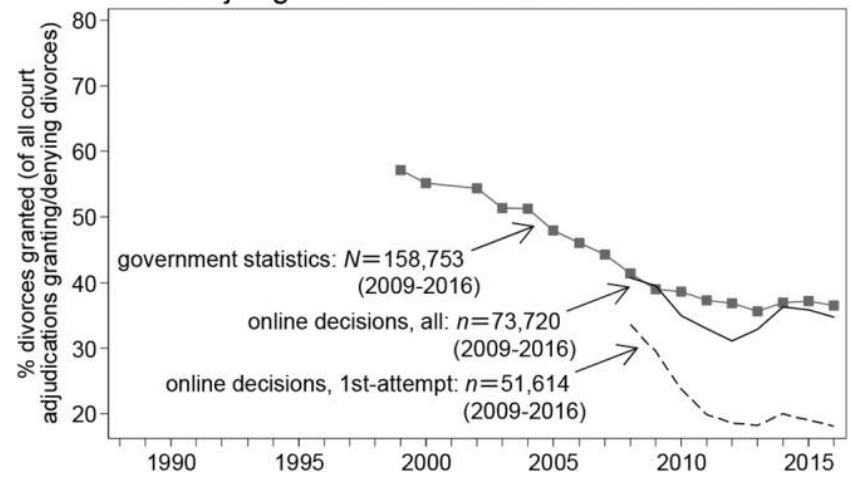

FIG. 1.-Granted divorces as a proportion of all decisions to grant or deny divorce petitions. Official government statistics and online decisions (all) correlated at $R=.98$ for Henan and $R=.79$ for Zhejiang. Zhejiang's 2001 data point is omitted because it is undoubtedly erroneous. Data disaggregated by province are unavailable for years prior to 1999. Data are from the Ministry of Civil Affairs of China, various years; author's calculations from Henan and Zhejiang provincial high courts' online decisions. 


\section{American Journal of Sociology}

from $62 \%$ to $44 \%$ in Henan, and from $56 \%$ to $47 \%$ in Zhejiang (Ministry of Civil Affairs of China, various years).

China's judicial clampdown on adjudicated divorce has been achieved in no small part on the backs on women. Table 3 shows that the long-dash lines in figure 1 vary greatly by plaintiff sex. Women's divorce requests were far less likely than men's to be granted on the first attempt. Women's disproportionate burden was compounded by four factors. First, as we can also see in table 3, women were disproportionately exposed to marital violence. In both Henan and Zhejiang, rates at which female plaintiffs made claims of domestic violence-38\% in Henan and 39\% in Zhejiang - are consistent with previously published estimates. Also consistent with previously published estimates, $90 \%$ and $87 \%$ of plaintiffs in the Henan and Zhejiang samples, respectively, who made abuse claims were women (Chen and Duan 2012, pp. 29-30; Li

TABLE 3

Frequency Distributions (\%) of Theoretical Variables, Overall and by Plaintiff Sex

\begin{tabular}{|c|c|c|c|c|c|c|}
\hline & \multicolumn{3}{|c|}{ HENAN $(n=54,200)$} & \multicolumn{3}{|c|}{ ZHEJIANG $(n=8,626)$} \\
\hline & \multirow{2}{*}{$\begin{array}{c}\text { All } \\
\text { Plaintiffs }\end{array}$} & \multicolumn{2}{|c|}{ By Plaintiff Sex } & \multirow{2}{*}{$\begin{array}{c}\text { All } \\
\text { Plaintiffs }\end{array}$} & \multicolumn{2}{|c|}{ By Plaintiff Sex } \\
\hline & & Female & Male & & Female & Male \\
\hline Sex composition of plaintiffs & 100.0 & 66.3 & 33.7 & 100.0 & 67.0 & 33.0 \\
\hline \multicolumn{7}{|c|}{ Court decision to grant or deny petition: } \\
\hline Divorce granted . . . . . . . & 36.9 & 33.4 & 43.9 & 20.4 & 16.5 & 28.2 \\
\hline Divorce denied . . . . . . . & 63.1 & 66.6 & 56.1 & 79.6 & 83.5 & 71.8 \\
\hline Total . & 100.0 & 100.0 & 100.0 & 100.0 & 100.0 & 100.0 \\
\hline \multicolumn{7}{|l|}{ Plaintiff claim of marital violence: } \\
\hline Apparent claim of violence ... & 28.0 & 38.1 & 8.3 & 29.7 & 38.7 & 11.4 \\
\hline No apparent claim of violence & 72.0 & 61.9 & 91.7 & 70.3 & 61.3 & 88.6 \\
\hline$\ldots \ldots \ldots \ldots \ldots \ldots \ldots$ & 100.0 & 100.0 & 100.0 & 100.0 & 100.0 & 100.0 \\
\hline \multicolumn{7}{|l|}{ Defendant consent: } \\
\hline \multicolumn{7}{|l|}{ Defendant in absentia: } \\
\hline public notice . . . . . & 12.5 & 9.2 & 19.0 & 6.2 & 4.2 & 10.2 \\
\hline no public notice & 22.6 & 24.0 & 19.8 & 23.1 & 23.9 & 21.5 \\
\hline \multicolumn{7}{|l|}{ Defendant consented } \\
\hline to divorce $\ldots . .$. & 15.4 & 14.8 & 16.4 & 14.2 & 13.8 & 15.2 \\
\hline \multicolumn{7}{|l|}{ Defendant withheld } \\
\hline consent ....... & 49.6 & 52.0 & 44.8 & 56.5 & 58.1 & 53.1 \\
\hline Total . & 100.1 & 100.0 & 100.0 & 100.0 & 100.0 & 100.0 \\
\hline
\end{tabular}

Note.-Limited to first-attempt divorce trials. The numbers of observations here and in table 2 (under "first attempts") are different because this table is limited to the subsample of observations with disclosed litigant sex and nonmissing values of covariates included in the logit regression models. All $\chi^{2}$ tests of differences between male and female plaintiffs are statistically significant at $P<.001$. Totals do not always equal $100.0 \%$ owing to rounding error. Results are from author's calculations from Henan and Zhejiang provincial high courts' online decisions. 
2015b, p. 168, 171; Runge 2015, p. 32; Zhao and Zhang 2017, pp. 193-94; Htun and Weldon 2018, p. 49).

Second, the improbability of obtaining an adjudicated divorce on the first attempt disproportionately impacted women in part because male defendants were more likely than female defendants to withhold consent. Table 3 shows that cases in which the defendant withheld consent represent by far the largest category of the "defendant consent" variable and account for at least one-half of all first-attempt divorce trials in each sample. Likewise, defendants in only a small proportion of cases $(15 \%$ and $14 \%$ in the Henan and Zhejiang samples, respectively) consented to divorce. Table 3 also shows that female plaintiffs were more likely than male plaintiffs to face defendant obstructionism and less likely than male plaintiffs to have defendant consent.

Third, as we can also see in table 3 , female plaintiffs were less than half as likely as male plaintiffs to have public notice trials. Because, as we will see, judges were relatively inclined to grant divorces when defendants were unable or chose not to participate in first-attempt trials, women's lower chances of success in their attempts to divorce are explained in part by men's vast overrepresentation among plaintiffs in public notice trials. ${ }^{13}$

Altogether about one-third of plaintiffs in each sample did not face defendants in their first-attempt trials. A far greater share of defendants were AWOL in Henan than in Zhejiang undoubtedly because Zhejiang is far more urbanized than Henan. As we know, defendants whose whereabouts are allegedly unknown or who opt out of court proceedings are overrepresented in rural areas. In rural county courts in my samples, 35\%-40\% of first-attempt trials were held without the participation of defendants, compared with only $15 \%-20 \%$ in the most urbanized courts in my samples.

Fourth, the foregoing dynamics that militated against women's efforts to divorce were multiplied by women's disproportionate representation among first-attempt divorce petitioners in court. Table 3 shows that, consistent with previously published estimates, women accounted for $66 \%$ and $67 \%$ of all plaintiffs filing first-attempt divorce petitions in the Henan and Zhejiang samples, respectively (Xu 2007, p. 199).

In this section I have shown that the endogenous legal test of breakdownism dominates Chinese judges' discourse in their published court

\footnotetext{
${ }^{13}$ Data limitations prohibit an assessment of the extent to which this overrepresentation is endogenous to courts. It could be a function of men's greater likelihood to claim missing spouses, courts' greater likelihood to accept the missing spouse claims of male plaintiffs, or a combination of both. Regardless of its origins, this overrepresentation disadvantages female plaintiffs relative to male plaintiffs. Although, as discussed earlier, a statutory basis for divorce stipulated by the Marriage Law is a formal missing person declaration by a court, my samples of court decisions reveal that this almost never happens, undoubtedly because, as also discussed earlier, courts can enjoy all the conveniences of a public notice trial without the hassle of making a formal missing person declaration.
} 
decisions. I also showed sizable gender gaps in plaintiffs' adjudication outcomes, plaintiffs' rates of claiming domestic violence, and defendants' unwillingness to divorce.

\section{MULTIVARIATE FINDINGS}

The descriptive evidence I have presented so far lends support to hypothesis $1 \mathrm{~b}$ by showing that, in my two provincial samples of divorce adjudications, judges referred overwhelmingly to the no-fault legal standard of breakdownism and rarely referred to faultism standards. Indeed, a defendant's lack of consent is often the only evidence judges need to deny divorce petitions according to the breakdownism standard (Xu 2007, p. 204). A holding such as this is common: "The defendant's unwillingness to divorce proves that marital relations between the plaintiff and defendant have not irreparably broken down" (Decision 965165, Fangcheng County People's Court, Henan Province, April 26, 2013). I will now test hypothesis 1 more rigorously by comparing the relative importance of these two competing standards on judges' decisions to grant and deny first-attempt divorce petitions. I use logit regression models to estimate both the effect of plaintiffs' domestic violence claims, which pertain to the legal standard of faultism, and the effect of defendants' consent, which pertains to the no-fault legal standard of breakdownism. Table 4 contains AMEs estimated from these models of judges' decisions to grant first-attempt divorces in the Henan and Zhejiang samples.

\section{Correlates of Adjudicated Divorces}

In model 1, which controls only for decision year and court, the AMEs for the gender gap in the probability of obtaining an adjudicated divorce-average female predicted probabilities minus average male predicted probabilitiesare -.09 in Henan and -.11 in Zhejiang. Model 2 adds claims of domestic violence. In both Henan and Zhejiang, a claim of domestic violence reduces the probability of obtaining a first-attempt adjudicated divorce by .09 and .04 in the Henan and Zhejiang samples, respectively. Model 2 also shows that the highly statistically significant gender gap is reduced by controlling for claims of domestic violence. As we will see, this negative effect of domestic violence in model 2 is largely an artifact of (1) an overrepresentation of domestic violence claims in cases in which defendants withheld consent (because judges rarely granted divorces in such cases) and (2) an underrepresentation of domestic violence claims in public notice trials (because judges were reasonably likely to grant divorces in such cases). In short, defendant consent is driving what appears to be an effect of domestic violence. 
TABLE 4

Average Marginal Effects on Courts' Granting Divorces, Calculated from Logistic Regression Models

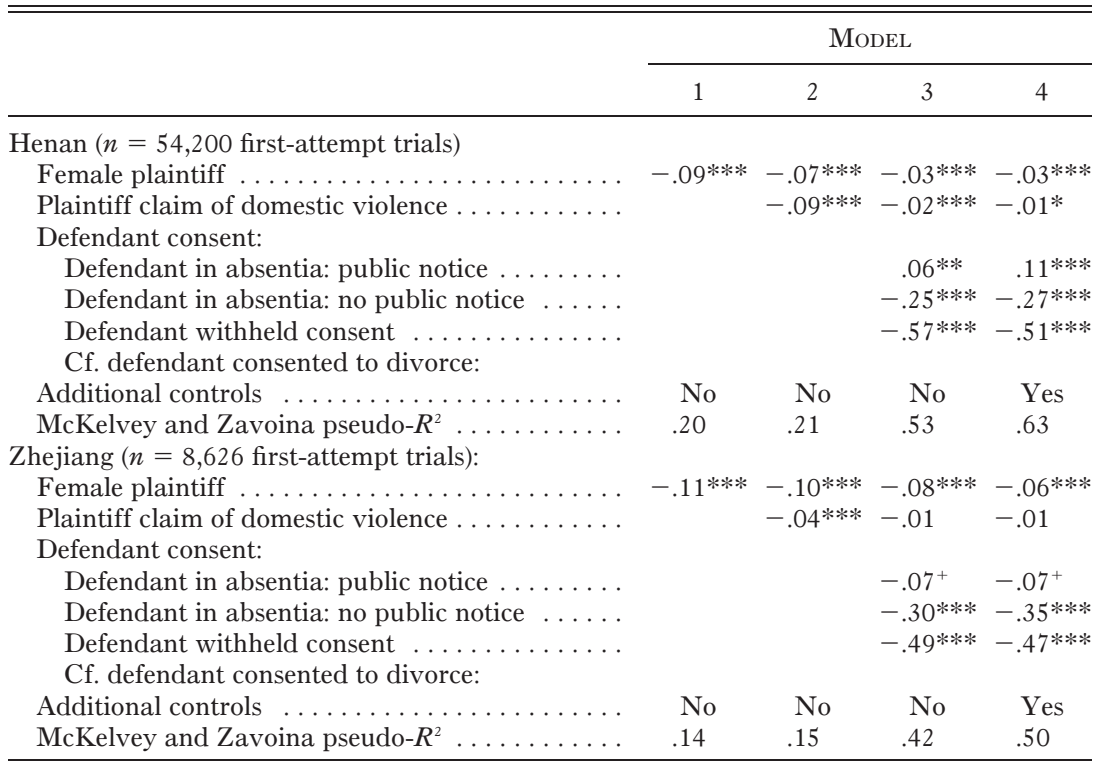

Note.-All models include court fixed effects (court dummies) and year of decision. Significance tests are based on SEs calculated using the delta method and are adjusted for nonindependence between decisions clustered within courts (161 and 91 in the Henan and Zhejiang samples, respectively). "Cf." denotes the omitted reference category. Results reflect author's calculations from Henan and Zhejiang provincial high courts' online decisions.

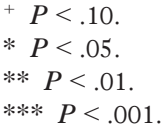

When defendant consent is introduced in model 3, the gender gap shrinks yet again, suggesting that some of the gender gap in the probability of obtaining an adjudicated divorce on the first attempt is due to female plaintiffs' greater exposure to domestic violence and spousal obstructionism and to the more limited use of public notice trials for their cases. Indeed, defendant consent accounts for the majority of the gender gap in the Henan sample. Just as striking as the shrinking gender gap is the sheer magnitude of the effect of defendant consent. Recall that satisfying statutory grounds for the breakdown of mutual affection is relatively straightforward both in public notice trials and when the defendant consents. Regression results show that only under these two circumstances is a court reasonably likely to grant a plaintiff's 
divorce request. In the full model (model 4), a spouse's unwillingness to divorce lowers the probability of obtaining a divorce by .51 and .47 in the Henan and Zhejiang samples, respectively. Diverging from the expectations of hypothesis $1 \mathrm{a}$ and lending overwhelming support to hypothesis $1 \mathrm{~b}$, the effect of defendants' withholding consent is greater than the effect of plaintiff domestic violence claims on divorce outcomes by dozens of orders of magnitude. Similarly, in absentia trials in which defendants were not served by public notice (because they were not alleged to be missing) reduced the probability of obtaining a divorce by .27 and .35 in the Henan and Zhejiang samples, respectively. The relatively minor importance of faultism standards and the major importance of breakdownism standards is also reflected in the minor change in pseudo- $R^{2}$ values between model 1 and model 2 and the major change in pseudo- $R^{2}$ values between model 2 and model $3 .{ }^{14}$

In both samples, defendant consent substantially reduces the effect of claiming domestic violence. When controlling for plaintiff sex and defendant consent in model 3, the effect of an apparent claim of domestic violence approaches irrelevance in both samples ( -.02 in Henan and -.01 in Zhejiang). Note that with the introduction of additional variables in subsequent models, the effect of a claim of domestic violence almost entirely disappears (although its effect of -.01 remains statistically significant in the Henan sample). Defendant consent explains away most of the effect of domestic violence claims for two reasons: (1) defendants who did not consent to divorce were disproportionately accused of perpetrating domestic violence and (2) plaintiffs were relatively unlikely to make claims of domestic violence in public notice trials. One obvious interpretation is that abusers also tend to be obstructionists. However, given limitations in the data, we cannot entirely rule out an alternative possibility that abuse claims are endogenous to spousal consent: some plaintiffs may make abuse claims because their spouses are unwilling to divorce. Similarly, although it seems highly plausible that plaintiffs are at much lower risk of domestic violence when their spouses are missing, we cannot entirely rule out an alternative possibility that missing spouses obviate plaintiffs' perceived need to make abuse claims.

We now have clues that help explain why male plaintiffs are more likely than female plaintiffs to succeed in their efforts to divorce on the first attempt. Women's sizable disadvantage in the probability of obtaining an adjudicated divorce stems from a triple whammy of gender differences in the incidence of domestic violence, defendant obstructionism (in the form of

${ }^{14}$ This pattern is mirrored by various pseudo- $R^{2}$ formulas, including adjusted count and McFadden's (for a discussion of competing pseudo- $R^{2}$ 's, see Long and Freese [2014, pp. 126-31]). 
withholding consent), and missing defendants. We also know that these costs are further amplified by a huge overrepresentation of women among plaintiffs filing for divorce in court.

Inconsistent with hypothesis $2 \mathrm{a}$ and supportive of hypothesis $2 \mathrm{~b}$, the marginal effect of a claim of abuse in the full model (model 4) is tiny in both samples, and below the threshold of statistical significance in the Zhejiang sample. Meanwhile, the effect of defendant consent remains immense. Defendant consent alone contributes more to pseudo- $R^{2}$ values than do all remaining control variables combined, including the court dummies. The effect of defendant consent towers above that of everything else in the model.

The evidence is unambiguous: in the Chinese context of divorce litigation, breakdownism is king and faultism is of practical irrelevance. Consistent with poignant anecdotal evidence of Chinese courts' general failure to grant divorces on the basis of domestic violence (Fincher 2014), claims of abuse clearly did not improve plaintiffs' chances of getting divorced in court, and, at least in the Henan sample, appear to have been counterproductive. This is precisely what we would expect if judges privilege breakdownism over faultism. Judges heed political calls to prevent frivolous divorce, preserve marriages, and reduce social instability. Even though their job is to rule on contentious disputes, they avoid entering the fray for fear of fallout from "extreme incidents" that might follow decisions that are intolerable to defendants they perceive as potentially violent. Under enormous pressure to close cases, they save time, enhance their work productivity, and improve their efficiency scores by disregarding and trivializing domestic violence claims. And, for cultural reasons, they look askance with suspicion at domestic violence claims as potentially exaggerated or fabricated.

Female plaintiffs remain disadvantaged in model 4 net of controls. Consistent with hypothesis 3 concerning gender bias, even among plaintiffs who were otherwise similar in terms of defendant consent, domestic violence claims, and an array of controls, women were still less likely than men to obtain an adjudicated divorce on the first attempt.

\section{Correlates of Gender Gaps in Adjudicated Divorces}

My final empirical task is to test hypotheses concerning specific contexts in which playing fields were relatively even and uneven between female and male plaintiffs. Table 5 goes beyond the contents of table 4 by presenting predicted probabilities, from which AMEs in table 4, model 4, were calculated.

Table 5 shows that the slightly negative effect of making a claim of domestic violence seen in table $4(-.01)$ is limited to female plaintiffs in the 
TABLE 5

Average Predicted Probabilities of Courts' Granting Divorces

\begin{tabular}{|c|c|c|c|c|}
\hline & \multirow{2}{*}{$\begin{array}{c}\text { All } \\
\text { Plaintiffs }\end{array}$} & \multicolumn{2}{|c|}{ By Plaintiff Sex } & \multirow{2}{*}{$\begin{array}{c}\text { Gender } \\
\text { Differences }\end{array}$} \\
\hline & & Female & Male & \\
\hline \multicolumn{5}{|l|}{ Henan: } \\
\hline Overall & .37 & .36 & .39 & $-.03 * * *$ \\
\hline \multicolumn{5}{|l|}{ Plaintiff claim of domestic violence: } \\
\hline a. Yes $\ldots \ldots \ldots \ldots \ldots \ldots$ & $.36^{\mathrm{b}}$ & $.34^{\mathrm{b}}$ & .40 & $-.06 * * * \mathrm{~b}$ \\
\hline b. No $\ldots \ldots \ldots \ldots \ldots \ldots \ldots$ & $.37^{\mathrm{a}}$ & $.37^{\mathrm{a}}$ & .39 & $-.02 * * * a$ \\
\hline \multicolumn{5}{|l|}{ Defendant consent: } \\
\hline $\begin{array}{l}\text { a. Defendant in absentia: public notice } \\
\text { b. Defendant in absentia: no public }\end{array}$ & $.77^{\mathrm{b}, \mathrm{c}, \mathrm{d}}$ & $.74^{\mathrm{b}, c, \mathrm{~d}}$ & $.84^{\mathrm{b}, \mathrm{c}, \mathrm{d}}$ & $-.09 * * * \wedge \mathrm{b}, \mathrm{c}, \mathrm{d}$ \\
\hline notice $\ldots \ldots \ldots \ldots \ldots \ldots \ldots$ & $.39^{\mathrm{a}, \mathrm{c}, \mathrm{d}}$ & $.34^{\mathrm{a}, \mathrm{c}, \mathrm{d}}$ & $.50^{\mathrm{a}, \mathrm{c}, \mathrm{d}}$ & $-.16 * * * a, c, d$ \\
\hline c. Defendant consented to divorce .... & $.66^{\mathrm{a}, \mathrm{b}, \mathrm{d}}$ & $.67^{\mathrm{a}, \mathrm{b}, \mathrm{d}}$ & $.65^{\mathrm{a}, \mathrm{b}, \mathrm{d}}$ & $.02^{+a, b}$ \\
\hline d. Defendant withheld consent ..... & $.15^{\mathrm{a}, \mathrm{b}, \mathrm{c}}$ & $.16^{\mathrm{a}, \mathrm{b}, \mathrm{c}}$ & $.14^{\mathrm{a}, \mathrm{b}, \mathrm{c}}$ & $.02 * * * a, b$ \\
\hline \multicolumn{5}{|l|}{ Zhejiang: } \\
\hline Overall ....... & .20 & .18 & .24 & $-.06 * * *$ \\
\hline \multicolumn{5}{|l|}{ Plaintiff claim of domestic violence } \\
\hline a. Yes $\ldots \ldots \ldots \ldots \ldots \ldots \ldots$ & .20 & .17 & .23 & $-.06^{*}$ \\
\hline b. No $\ldots \ldots \ldots \ldots \ldots \ldots$ & .21 & .18 & .24 & $-.06 * * *$ \\
\hline \multicolumn{5}{|l|}{ Defendant consent: } \\
\hline $\begin{array}{l}\text { a. Defendant in absentia: public notice } \\
\text { b. Defendant in absentia: no public }\end{array}$ & $.47^{\mathrm{b}, \mathrm{d}}$ & $.39^{\mathrm{b}, \mathrm{c}, \mathrm{d}}$ & $.63^{\mathrm{b}, \mathrm{d}}$ & $-.23 * * * \wedge c, \mathrm{~d}$ \\
\hline notice $\ldots \ldots \ldots \ldots \ldots \ldots$ & $.20^{\mathrm{a}, \mathrm{c}, \mathrm{d}}$ & $.14^{\mathrm{a}, \mathrm{c}, \mathrm{d}}$ & $.31^{\mathrm{a}, \mathrm{c}, \mathrm{d}}$ & $-.16 * * * \wedge c, d$ \\
\hline c. Defendant consented to divorce .... & $.55^{\mathrm{b}, \mathrm{d}}$ & $.54^{\mathrm{a}, \mathrm{b}, \mathrm{d}}$ & $.56^{\mathrm{b}, \mathrm{d}}$ & $-.03^{\wedge \mathrm{a}, \mathrm{b}}$ \\
\hline d. Defendant withheld consent ..... & $.07^{\mathrm{a}, \mathrm{b}, \mathrm{c}}$ & $.07^{\mathrm{a}, \mathrm{b}, \mathrm{c}}$ & $.07^{\mathrm{a}, \mathrm{b}, \mathrm{c}}$ & $-.002^{\mathrm{a}, \mathrm{b}}$ \\
\hline
\end{tabular}

NotE.-All contents of this table are postestimation calculations from the same models used to make the postestimation calculations of AMEs in table 4, model 4. A caret $\left(^{\wedge}\right)$ denotes a slight discrepancy due to rounding error between an AME (in the "gender differences" column) and the corresponding predicted probabilities from which it was calculated (in the "by plaintiff sex" columns). Likewise, differences between predicted probabilities in this table are not always identical to corresponding AMEs in table 4 owing to rounding error. Superscript letters correspond to other categories of the same variable. Known as contrasts, they denote the statistical significance (at $P<.05$ ) of differences between variable categories (first differences). In the "gender differences" column, they also denote the statistical significance (at $P<.05$ ) of gender gaps (second differences) across different variable categories. On contrasts, see Long and Freese (2014, p. 252) and Mize (2019, p. 106). Results reflect author's calculations from Henan and Zhejiang provincial high courts' online decisions.

$+P<.10$, two-tailed tests.

$* P<.05$.

** $P<.01$.

*** $P<.001$.

Henan sample. In Henan, claims of domestic violence widened the gender gap considerably. Whereas the gender gap was only -.02 among plaintiffs who did not make such a claim, it was a much wider -.06 among plaintiffs who did make such a claim. The difference between these two gender gaps (a test of second difference) is statistically significant. Thus, hypothesis $4 \mathrm{~b}$ 
finds strong support from the Henan sample: the negative effect of making a claim of domestic violence was greater for female plaintiffs than for male plaintiffs. The obvious interpretation of this pattern is that judges treated men's domestic violence claims more seriously than women's domestic violence claims; they more readily dismissed women's domestic violence claims as unimportant or fabricated. In the Zhejiang sample, by contrast, domestic violence claims were equally irrelevant to women and men alike.

In table 5 we see once again that plaintiffs' divorce prospects were highest when they passed the breakdownism test with either a public notice trial or defendant consent. The overall predicted probability of a granted divorce in a public notice trial (.77 in Henan and .47 in Zhejiang) was more than double the overall probability (.37 in Henan and .20 in Zhejiang). In Henan, plaintiffs' chances of getting divorced were even higher in this type of trial (.77) than in trials in which the defendant expressed consent to divorce (.66). By contrast, when defendants failed to participate in court proceedings for other reasons, overall predicted outcomes were about the same as in all trials taken together. Public notice trials and mutual consent were by far the most realistic pathways to divorce. They were also the least common pathways, together accounting for only $20 \%-25 \%$ of first-attempt divorce trials in both samples.

Although plaintiffs as a whole benefited from in absentia trials only when an allegedly missing defendant was served by public notice (thus satisfying the breakdownism standard), male plaintiffs enjoyed a large and statistically significant advantage over female plaintiffs when defendants failed to participate in court proceedings for any reason. Lending strong support to hypothesis 5 , gender differences in the probability of a divorce on the first attempt, ranging from -.09 to -.23 , were massive and statistically significant in both samples when defendants were AWOL, regardless of how the court served the defendant. Indeed, for a male plaintiff in the Henan sample, divorce approached a forgone conclusion (.84) in a public notice trial. Tests of second difference show that, among all in absentia trials, public notice trials narrowed the gender gap in Henan $(-.16$ vs. -.09 , a statistically significant difference) and widened the gender gap in Zhejiang $(-.16$ vs. -.23 , a statistically insignificant difference).

Women's severe disadvantage in the context of in absentia trials-both as plaintiffs and as defendants - is consistent with patriarchal cultural beliefs about women as less credible and less deserving than men. My empirical findings suggest that judges, who themselves are mostly men, took claims about missing spouses more seriously and treated them as more credible when they were made by male plaintiffs. The court decisions in my samples reflect cultural narratives not only about female plaintiffs making false claims of domestic violence in illicit efforts to abscond with marital property and child custody (Epstein and Goodman 2018), but also about female 
plaintiffs who, for the same reasons, falsely conceal the whereabouts of their husbands. The court decisions may further reflect judges' implicit belief that missing female defendants, particularly those they suspect are in illicit extramarital relationships, are less deserving than male defendants of the legal protections and due process they lose when they are absent from trials. In short, judges are far more inclined to protect husbands than to protect wives from getting "unwittingly divorced."

Courts were also relatively inclined to grant divorces to plaintiffs when defendants expressed their consent. However, data from neither sample support the expectation of hypothesis 6 that female plaintiffs were disadvantaged when both sides agreed to part ways. In the Zhejiang sample, mutual consent put women at a small but statistically insignificant disadvantage (-.03). Quite the contrary in the Henan sample, where courts were more inclined to grant divorces to female plaintiffs than to male plaintiffs in the context of mutual consent, albeit to only a small (.02) and marginally statistically significant extent.

Finally, an adjudicated divorce was highly improbable in the absence of spousal consent. According to model 4, the average predicted probability of obtaining an adjudicated unilateral divorce among plaintiffs whose spouses withheld consent was only .15 in Henan and .07 in Zhejiang. In the context of defendants who withheld consent to divorce, female and male plaintiffs were on a playing field that was similarly harsh to everyone. Adjudicated unilateral divorce prospects were slim for female and male plaintiffs alike on the first attempt. Consistent with hypothesis 7, the chances of female and male plaintiffs seeking unilateral divorces in Zhejiang were identical. Contrary to the expectations of hypothesis 7 , however, female plaintiffs in Henan had a small (.02) but statistically significant advantage over male plaintiffs when defendants withheld consent.

To sum up my empirical findings, mutual consent and public notice trials, key statutory conditions of the breakdown of mutual affection, were the only realistic pathways to divorce on the first attempt. Domestic violence, by contrast, a competing fault-based statutory condition, did not move the needle toward divorce. Victims of domestic violence, almost all of whom were women, were revictimized by judges who, at best, ignored their claims. Although breakdownism prevailed over faultism by a massive margin, judges did not apply the breakdownism standard equally. Judges showed a far greater inclination to affirm the breakdown of mutual affection on the basis of a missing defendant when the plaintiff was a man. Women's overall disadvantage in getting a divorce on the first attempt is attributable in large measure to their specific disadvantage in trials in which defendants were missing or refused to participate. Male litigants - both plaintiffs and defendants alikeenjoyed preferential treatment from judges in in absentia trials. Judges were far more reluctant to grant the divorce requests of female plaintiffs in the 
absence of their husbands than they were to grant the divorce petitions of male plaintiffs in the absence of their wives.

\section{DISCUSSION AND CONCLUSIONS}

In this article, I have documented the extent to which and provided reasons why women have borne the brunt of Chinese courts' clampdown on adjudicated divorce. Generally speaking, divorce is readily attainable outside the court system if both sides are willing and can agree on all terms. Courts are the only place in China to which people can take contested, unilateral, ex parte divorces. China's divorce laws on the books provide strong protections to women seeking divorce. Chinese courts, however, routinely stretch these laws beyond recognition or altogether ignore them, and in so doing subvert China's own laws and international legal commitments. The evidence is clear: an apparent claim of domestic violence has no meaningful influence on whether a court grants an adjudicated divorce. In China's divorce courts, domestic laws and global legal norms concerning violence against women have been sidelined to the point of irrelevance. By privileging competing institutional imperatives, including judicial efficiency, the preservation of marriages, and social stability maintenance, courts serve the needs of political priorities more than the needs of gender justice. As political pressure to preserve marriages has grown, so too has courts' tendency to deny divorce petitions, even when-or especially when-they include claims of domestic violence.

Had I measured China's "trial fairness" according to its formal laws and international treaty commitments summarized by the U.S. State Department in its human rights reports (Hathaway 2002), I would have arrived at very different conclusions. Had I assessed Chinese court behavior according to vignettes presented to lawyers or to ordinary citizens (most of whom had never been to court; Wang 2014; Negro and Longhofer 2018), or according to panels of regional and country "experts" (Cole 2012, 2015; Hafner-Burton and Tsutsui 2005; Htun and Weldon 2018), my conclusions would likewise have been different. Contrary to much of the literature on the diffusion and local penetration of global legal norms, my conclusions about judicial behavior and trial fairness come from empirical analysis of actual judicial behavior and actual trials.

Real decisions from real courts show that, over time, adjudicated divorce became increasingly difficult in general and were disproportionately difficult for women in particular. My empirical findings show that the wide gender gap in the probability of getting an adjudicated divorce on the first attempt is explained in large measure by five correspondingly wide gender gaps in (1) the incidence of plaintiffs with domestic violence claims, (2) the incidence of plaintiffs whose spouses withheld consent, (3) judges' gendered 
responses to plaintiffs' claims of domestic violence, (4) judges' gendered responses to plaintiffs' claims of missing spouses, and (5) judges' gendered responses to defendants' failure to appear in court for other reasons.

Chinese judges deny first-attempt divorce requests for fear that plaintiffs, particularly female plaintiffs, embellish and lie; for fear that the approval process will slow the rate at which they clear cases; and for fear that angry husbands will cause "extreme incidents" of social unrest by retaliating against plaintiffs. Undoubtedly, some plaintiffs do exaggerate and altogether fabricate their claims. The degree to which judges believe they do so, however, varies by plaintiff sex. Judges, under the influence of cultural stereotypes about gender, give greater credence to the claims of male plaintiffs and attach greater value to the rights of male defendants. When ruling on first-attempt divorce petitions, judges seem far more fearful of supporting a case without merit than denying a case with merit. On the whole, they would rather send a woman home with her abuser or force her into hiding than to grant a divorce to a woman who wants out of an unhappy marriage and may have thought spinning a poignant story about abuse would improve her chances of achieving her goal. Even if some plaintiffs (however few) lie in court proceedings about abuse or the whereabouts of their spouses, is it better for judges to preserve the marriage than to dissolve it? Is the judicial error of dissolving the marriage of an unhappy woman who may have lied about or exaggerated abuse claims worse than the judicial error of exposing a battered woman to ongoing abuse by prolonging her marriage against her wishes? Would it not be better to err on the side of protecting women?

The social and public health implications of China's "divorce twofer" are palpable: this institutionalized norm of denying a divorce request on the first attempt and granting it on a subsequent attempt has spawned a sizable population of female marital-violence refugees. In Henan and Zhejiang alone, thousands of women awaiting a second or third chance for an adjudicated divorce must choose from an array of similarly horrific options: further subjection to marital violence; separation from children, aging parents, and other kin; and economic vulnerability from forfeiting marital property and eking out an existence a safer distance from abusive husbands.

My empirical findings on marital decoupling in China also shed light on institutional decoupling - the extent to which and reasons why legal systems that bear the symbolic hallmarks of global legal norms subvert them in practice. Decades of research on local compliance with global norms documents a ubiquitous gap between doctrinal law and on-the-ground practices, and the ubiquity of hollow and symbolic commitments to world society values. Do previous explanations for the extent and character of decoupling between global legal commitments and local legal practices in general help us make sense of decoupling in the specific context of Chinese divorce litigation? The ratification of CEDAW, which scholars argue helps explain 
international variation in the gap between promises and practices (Englehart and Miller 2014; Htun and Weldon 2018; Wang and Schofer 2018), appears to have had little impact on the protection of Chinese domestic violence victims unilaterally seeking divorce in court. Of course, we have no way of knowing whether the plight of Chinese women seeking freedom from their abusive husbands would have been even worse in its absence. Furthermore, divorce litigation is only one piece of the larger puzzle of gender violence, and perhaps China's ratification of CEDAW has helped women in other institutional contexts.

Can we make sense of China's divorce twofer as a function of bureaucratic capacity (Cole 2015)? While a greater supply of judges and other court personnel, by alleviating some of the pressures of crushing dockets that motivate judges to deny first-attempt divorce petitions, might help women seeking divorce, the institutional roots of the divorce twofer also lie elsewhere. Can we attribute gender injustice in China's civil courts to the absence of a strong and autonomous domestic feminist women's movement (Htun and Weldon 2018)? While we can only speculate about the hypothetical impact of such a movement on judicial practices in China, we can be confident that the more salient institutional roots of China's divorce twofer lie with the endogenous institutional logics of a political ideology hostile to divorce and with performance evaluation systems that incentivize adjudicated denials of divorce petitions. That the empirical patterns I presented are so consistent across two subnational contexts that differ in other ways suggests the power of the endogenous institutional logics at the heart of my explanation. The clampdown on divorce litigation is no less severe in Zhejiang, which, as a coastal province adjoining Shanghai in one of the most prosperous parts of China, is more integrated with and proximate to world society than Henan is. Contrary to the expectations of world society theory, adjudicated divorce is considerably harder to come by in Zhejiang than in Henan, perhaps in part because, as mentioned earlier, judges in Zhejiang have the heaviest dockets in China.

In the context of Chinese divorce litigation, the direction of institutional "drift" (Schofer and Hironaka 2005) has been away from at least as much as toward global norms. The "paradox of empty promises" (Hafner-Burton and Tsutsui 2005) in the context of Chinese divorce litigation is the extent to which courts are a primary obstacle to the realization of the promises enshrined in laws intended to protect women's freedom of divorce and to offer relief to victims of marital violence. We cannot understand Chinese courts' routine failure to offer relief from domestic violence as merely a matter of compliance failure. On the contrary, to a real extent we should understand the judicial practices I have documented in this article as compliance success. Courts' routine failure to protect victims of domestic violence is a function of purposeful institutional design. As we have seen, judges' seemingly 
limitless discretion to assess marital quality, reconciliation potential, and evidence submitted by litigants is hardly a problem of implementation, much less an unintended consequence of institutional design flaws. The logic of the breakdownism standard is its subjectivity and flexibility for the intended purpose of allowing judges to apply it (pliably) in ways that support prevailing political priorities. China's enduring political priority of preventing frivolous divorce has a long legacy and has taken on renewed urgency since 2012. The real paradox is that Chinese judges are expected to subvert and stretch beyond recognition domestic laws that are "constructed out of a common and universalistic world cultural frame" (Boyle and Meyer 1998, p. 214) and are rewarded for doing so.

According to Pope and Meyer (2016, pp. 289-90), "Decoupling exists because world models, which are suffused with meaning and cultural significance, interface with situated interests and practical concerns at the local level (Meyer and Rowan 1977). Local actors may adopt the models for reasons of external legitimacy but buffer the models from daily practices to maintain internal technical efficiency or solidarity." A key methodological task, then, is properly identifying and measuring the relevant local "situated interests" and "practical concerns." From the existing literature on the topic we should expect that the extent to which China's commitments to women's rights, including the right to divorce, are decoupled from on-the-ground practices is a function, above all, of its links to world society, its bureaucratic capacity, and the strength and autonomy of its domestic feminist women's movement (Englehart and Miller 2014; Cole 2015; Htun and Weldon 2018; Wang and Schofer 2018). But of course we cannot assess the relative importance of multiple and potentially contradictory norms in a given institutional context before knowing what they are and how they work in theory and practice. As Drori and Krücken (2009, p. 20) put it, "The research methodologies common to world society theory have not allowed for specific findings that explain different degrees of coupling or pointed to the cultural and historical specificity of the determining societal context."

Insofar as a key objective of macrocomparative cross-national research on states' promises and practices is to assess the relative importance of endogenous and exogenous influences, essential methodological ingredients include appropriate measures of endogenous influences well attuned to local contexts. Only after first inductively ascertaining the endogenous norms and practices - legal and otherwise - that pertain to a specific context would we know what to compare with exogenous world society norms and practices (Fourcade and Savelsberg 2006; Hagan, Levi, and Ferrales 2006; Halliday and Carruthers 2009). Might empirical findings in the world society literature consistently showing stronger exogenous effects be an artefact of dominant approaches to measuring endogenous influences? Any comparison of global and local effects will necessarily privilege the former if salient endogenous 
norms and practices obstructing the realization of exogenous institutional prescriptions are poorly measured or altogether omitted from the analysis. We will not find what we do not know to look for; we cannot assess what we do not know to include in the assessment. For example, in their crossnational research on divorce rates, Wang and Schofer (2018, p. 20) find that global cultural norms valorizing "individual freedom, consent, and gender equality" trump local cultural and institutional barriers to divorce, which they measure as economic development, religious tradition, mass education enrollment (all of which theoretically drive cultural values conducive to divorce), and female labor force participation (which theoretically promotes women's financial wherewithal to divorce). China's perfect score of 3 out of 3 (over a period of almost 40 years) on a "divorce law equality" index (with higher scores meaning greater gender equality, constructed from components of Htun and Weldon's [2015] "family law index") belies the endogenous Chinese legal standard of breakdownism - altogether invisible in this scholarly literature - routinely used to deny first-attempt divorces to plaintiffs, and especially to female plaintiffs, particularly when they make claims of marital violence.

To be sure, China's rising divorce rates are consistent with Wang and Schofer's (2018, p. 16) sanguine conclusion that "the legitimation of world cultural principles at the global level can propel local change." Global scripts, including "developmental idealism," may very well contribute to values of individualism, feminism, and equal rights in China and may thus influence individual behavior (Boyle et al. 2002; Yu and Xie 2015; Thornton and Xie 2016) in the context of marriage and divorce despite durable local organizational barriers to divorce rooted in endogenous institutional norms and practices that are orthogonal to world society models. Such local organizational barriers are the focus of this article. If we know what to look for and where to look for it, we will surely find similar decoupling processes in other contexts characterized by local agents who, for material, ideological, political, cultural, and cognitive reasons, faithfully enforce endogenous institutional norms hostile to the very elements of world society they simultaneously champion. Such decoupling processes are all too often obscured by the local embrace of world society norms captured in macrocomparative cross-national research because they are more conspicuous on the surface veneer of institutions.

We must remain mindful of the substantive trade-offs of our methodological choices for other reasons, too. In-depth case studies such as this one are, by definition, poorly suited for generalizable research spanning wide swaths of time and place. They are also relatively narrow in the scope of the institutional issues they can address. In more concrete terms, the broader institutional issue of gender justice cannot be reduced to the specific issue of divorce practices in lower civil courts, the empirical focus of this article. Although this is a study of only one narrow slice of gender justice in one 
country, it provides a critical test for theories of local compliance with global norms. Is there a more likely place than the court system for the implementation of domestic laws such as China's that are so consistent with global legal norms? If a particular set of global legal norms embedded in domestic laws generally fails to penetrate the courts, perhaps we should harbor doubts about the prospects of world society penetration in other organizational contexts.

Perhaps the story has begun to change following the enactment of China's new 2015 Anti-Domestic Violence Law, which brings together and elaborates existing provisions on legal protections, including domestic violence protection orders, previously scattered across a number of bodies of law, administrative regulations, and SPC interpretations. Because this law was passed only shortly before all courts were prohibited from publishing divorce decisions online in October 2016, we will need another source of data to assess its impact more thoroughly. Nonetheless, we can look for early clues in the portion of decisions in my Zhejiang sample that were made after this law took effect on March 1, 2016. Although all the decisions in my Henan sample predate the implementation of this law, 10,501 adjudicated decisions in my full Zhejiang sample were made on or after March 1, 2016. In the solitary decision (one out of 10,501) in which this new body of law is cited, the plaintiff claimed to have been cut and injured in a knife attack by the defendant. In its written decision, the court cited this new body of law to justify denying the plaintiff's petition on the grounds that the plaintiff waited two years to file for divorce following the alleged attack and failed to submit relevant evidence, and, above all, that the defendant both denied the plaintiff's claim of abuse and was unwilling to divorce (Decision 4687109, Haiyan County People's Court, Zhejiang Province, September 1, 2016). The enactment of this special body of law, so far at least, has apparently done more to signal a symbolic commitment to combatting domestic violence than to change judicial practices on the ground. A Chinese report cited by Amnesty International drew a similarly discouraging conclusion: "10 months after the enactment of the [AntiDomestic Violence] law, of the 142 abuse-related divorce cases in the city of Jinan, only 14 cases were allowed to get divorced [sic]. The reason these 14 cases were successful were invariably the same [sic]: the accused admitted to abusing the victim. In the rest of the cases, failure was also invariably due to the same reason: the accused denied allegations of domestic violence, and judges deemed the cases to have insufficient proof" (Lu 2018).

My research is not without limitations. Among the endogenous institutional norms and pressures I identified that, I argue, account for decoupling in China's divorce courts, I can only speculate about the relative importance of each. Although my explanation for why judges privilege breakdownism over faultism includes a mix of several reasons, I cannot say whether the mix is equally distributed or tilts toward one or more of these reasons. Qualitative 
interviews with and observations of judges may reveal the extent to which they respond to some of these reasons more than others. Qualitative interviews with divorce litigants will also shed important light on their experiences and outcomes not only on the first attempt, but also vis-à-vis the choices they make concerning whether, when, and how to pursue divorce after an adjudicated denial on the first attempt. Finally, future research will assess the extent to which endogenous institutional norms influence not only whether to grant a first-attempt divorce petition but also judicial rulings on child custody and property division when judges do grant divorces.

\section{APPENDIX}

Legal Sources

Anti-Domestic Violence Law of the People's Republic of China (中华人民共 和国反家庭暴力法), adopted at the 18th session of the 12th National People's Congress, December 27, 2015, effective March 1, 2016.

Guidelines on Judging Marital Cases Involving Domestic Violence (涉及 家庭暴力婚姻案件审理指南), issued March 2008 by the China Institute of Applied Jurisprudence of the Supreme People's Court (最高人民法院中国应用 法学研究所).

Marriage Law of the People's Republic of China (中华人民共和国婚姻法), adopted at the seventh session of the 22nd Government Administration Council of Central People's Government, March 3, 1950; amended at the third session of the Fifth National People's Congress, September 10, 1980; amended at the 21st meeting of the Standing Committee of the Ninth National People's Congress, April 28, 2001.

\section{REFERENCES}

Ahl, Björn, and Daniel Sprick. 2018. "Towards Judicial Transparency in China: The New Public Access Database for Court Decisions.” China Information 32 (1): 3-22.

Alford, William P., and Yuanyuan Shen. 2004. "Have You Eaten? Have You Divorced? Debating the Meaning of Freedom in Marriage in China." Pp. 234-63 in Realms of Freedom in Modern China, edited by William Kirby. Stanford, CA: Stanford University Press.

Allison, Paul D. 1999. "Comparing Logit and Probit Coefficients across Groups." Sociological Methods and Research 28 (2): 186-208.

An, Chenxi (安晨曦). 2015. “民事诉讼立法预期与运行效果的背离及修正：以《民事诉讼法》 新制度实施状况为范例的分析 (Gaps between Expectations and Outcomes of Civil Procedure Legislation and Their Remedies: An Analysis of the Implementation of the New Civil Procedure Law System).” 现代法学 (Modern Law Science) 37 (6): 173-84.

Bartley, Tim. 2018. Rules without Rights: Land, Labor, and Private Authority in the Global Economy. New York: Oxford University Press. 


\section{American Journal of Sociology}

Bartley, Tim, and Niklas Egels-Zandén. 2016. "Beyond Decoupling: Unions and the Leveraging of Corporate Social Responsibility in Indonesia." Socio-Economic Review 14 (2): 231-55.

Boli, John, and Frank J. Lechner. 2001. "Globalization and World Culture.” Pp. 6261-66 in International Encyclopedia of the Social and Behavioral Sciences, edited by Neil J. Smelser and Paul B. Baltes. Oxford: Pergamon Press.

Boli, John, and George M. Thomas. 1997. "World Culture in the World Polity: A Century of International Non-Governmental Organization." American Sociological Review 62 (2): 171 .

Boyle, Elizabeth Heger, Barbara J. McMorris, and Mayra Gómez. 2002. "Local Conformity to International Norms: The Case of Female Genital Cutting." International Sociology 17 (1): 5-33.

Boyle, Elizabeth Heger, and John W. Meyer. 1998. "Modern Law as a Secularized and Global Model: Implications for the Sociology of Law.” Soziale Welt 49 (3): 275-94.

Bu, Xiaohong (卜晓虹), Xiaoting (黎晓婷) Li, and Xi (林曦) Lin. 2015. ““司法男权化”现象探 析与解决之路: 以基层法院离婚案庭审为视角 (An Analysis of and Solution to 'Judicial Patriarchalization': From the Perspective of Basic-Level Court Divorce Cases).” 法治论坛 (Nomocracy Forum) 4:3-18.

Buck, Pearl S. 1931. "Chinese Women: Their Predicament in the China of Today." $\underline{P a-}$ cific Affairs 4 (10): 905-9.

Cai, Lidong, and Yingcheng Qi. 2019. "Judicial Governance of 'Fake Divorce' with Chinese Characteristics: Practical Rationality of the Chinese Courts in the Transitional Period." China Review 19 (2): 99-123.

Chang, Zhaojun (常照军). 2017. “夫妻琐事闹离婚法官倾心来调解 (Trivial Quarrel Causes Divorce Dispute, Judge Enthusiastically Mediates).” http://www.hncourt.gov.cn/public /detail.php?id=168994. Accessed August 16, 2018.

Chen, Wei (陈苇), and Weiwei (段伟伟) Duan. 2012. “法院在防治家庭暴力中的作用实证研究 (Empirical Research on the Function of Courts in the Prevention of Domestic Violence).” 河北法学 (Hebei Law Science) 8:28-38.

Chen, Xiaoyong (陈小勇). 2005. “论离婚自由与反对轻率离婚 (On the Freedom of Divorce and Opposition to Frivolous Divorce).”湖南科技学院学报 (Journal of Hunan University of Science and Engineering) 1:154-56.

Chen, Xuefei (陈雪飞). 2007. “离婚案件审理中法官话语的性别偏向 (Gender Bias in Judges' Discourse during Divorce Trials).” 北大法律评论 (Peking University Law Review) 8 (2): 386-411.

Cheng, Le, and Xin Wang. 2018. "Legislative Exploration of Domestic Violence in the People's Republic of China: A Sociosemiotic Perspective." Semiotica 2018 (224): 249-68.

Cole, Wade M. 2005. "Sovereignty Relinquished? Explaining Commitment to the International Human Rights Covenants, 1966-1999." American Sociological Review 70 (3): 472-95.

- 2012. "Human Rights as Myth and Ceremony? Reevaluating the Effectiveness of Human Rights Treaties, 1981-2007.” American Journal of Sociology 117 (4): 1131-71.

_. 2013. "Strong Walk and Cheap Talk: The Effect of the International Covenant of Economic, Social, and Cultural Rights on Policies and Practices.” Social Forces 92 (1): $165-94$

. 2015. "Mind the Gap: State Capacity and the Implementation of Human Rights Treaties." International Organization 69 (2): 405-41.

Dezalay, Yves, and Bryant G. Garth. 2010. Asian Legal Revivals: Lawyers in the Shadow of Empire. Chicago: University of Chicago Press.

DiMaggio, Paul J., and Walter W. Powell. 1983. "The Iron Cage Revisited: Institutional Isomorphism and Collective Rationality in Organizational Fields." American Sociological Review 48 (2): 147. 
Dong, Wei (董巍), and Changsheng (纪长胜) Ji. 2016. “公告类离婚纠纷案件中的裁判问题 (Issues Concerning Judicial Decision-Making in Public Notice Divorce Disputes).” 天津法学 (Tianjin Legal Science) 128:88-93.

Drori, Gili S., and Georg Krücken. 2009. "World Society: A Theory and a Research Program in Context." Pp. 3-35 in World Society: The Writings of John W. Meyer, edited by John W. Meyer, Georg. Krücken, and Gili S. Drori. Oxford: Oxford University Press.

Edelman, Lauren B. 2016. Working Law: Courts, Corporations, and Symbolic Civil Rights. Chicago: University of Chicago Press.

Englehart, Neil A., and Melissa K. Miller. 2014. "The CEDAW Effect: International Law's Impact on Women's Rights.” Journal of Human Rights 13 (1): 22-47.

Epstein, Deborah, and Lisa A. Goodman. 2018. "Discounting Women: Doubting Domestic Violence Survivors.” University of Pennsylvania Law Review 167:399-461.

Feng, Yuqing, and Xin He. 2018. "From Law to Politics: Petitioners' Framing of Disputes in Chinese Courts." China Journal 80:130-49.

Fincher, Leta Hong. 2014. Leftover Women: The Resurgence of Gender Inequality in China. London: Zed Books.

Fourcade, Marion, and Joachim J. Savelsberg. 2006. "Introduction: Global Processes, National Institutions, Local Bricolage: Shaping Law in an Era of Globalization." Law and Social Inquiry 31 (3): 513-19.

Frank, David John, Bayliss J. Camp, and Steven A. Boutcher. 2010. "Worldwide Trends in the Criminal Regulation of Sex, 1945 to 2005." American Sociological Review 75 (6): 867-93.

Frank, David John, Tara Hardinge, and Kassia Wosick-Correa. 2009. "The Global Dimensions of Rape-Law Reform: A Cross-National Study of Policy Outcomes." American Sociological Review 74 (2): 272-90.

Frank, David John, Ann Hironaka, and Evan Schofer. 2000. "The Nation-State and the Natural Environment over the Twentieth Century." American Sociological Review 65 (1): 96-116.

Frank, David John, and Dana M. Moss. 2017. "Cross-National and Longitudinal Variations in the Criminal Regulation of Sex, 1965 to 2005." Social Forces 95 (3): 941-69.

Frohmann, Lisa. 1991. "Discrediting Victims' Allegations of Sexual Assault: Prosecutorial Accounts of Case Rejections.” Social Problems 38 (2): 213-26.

Fu, Ailing, and Jian Wang. 2019. "Till Death, Purchase of Another House, or Occurrence of Other Events Do Us Part: Interests-Oriented Fake Divorce Cases in China." Journal of Divorce and Remarriage 60 (2): 152-70.

Glynn, Mary Ann, and Ryan Raffaelli. 2013. "Logic Pluralism, Organizational Design, and Practice Adoption: The Structural Embeddedness of CSR Programs.” Pp. 17597 in Institutional Logics in Action, Part B, edited by Michael Lounsbury and Eva Boxenbaum. Bingley, UK: Emerald.

Goodmark, Leigh. 2005. "Telling Stories, Saving Lives: The Battered Mothers' Testimony Project, Women's Narratives, and Court Reform.” Arizona State Law Journal 37:709-57.

Hafner-Burton, Emilie M., and Kiyoteru Tsutsui. 2005. "Human Rights in a Globalizing World: The Paradox of Empty Promises." American Journal of Sociology 110 (5): 1373-1411.

Hafner-Burton, Emilie M., Kiyoteru Tsutsui, and John W. Meyer. 2008. "International Human Rights Law and the Politics of Legitimation." International Sociology 23 (1): $115-41$.

Hagan, John, Ron Levi, and Gabrielle Ferrales. 2006. "Swaying the Hand of Justice: The Internal and External Dynamics of Regime Change at the International Criminal Tribunal for the Former Yugoslavia." Law and Social Inquirv 31 (3): 585-616. 


\section{American Journal of Sociology}

Haley, Usha C. V., and George T. Haley. 2016. "Think Local, Act Global: A Call to Recognize Competing, Cultural Scripts." Management and Organization Review 12 (1): 205-16.

Hallett, Tim. 2010. "The Myth Incarnate: Recoupling Processes, Turmoil, and Inhabited Institutions in an Urban Elementary School." American Sociological Review 75 (1): $52-74$

Halliday, Terence C., and Bruce G. Carruthers. 2009. Bankrupt: Global Lawmaking and Systemic Financial Crisis. Stanford, CA: Stanford University Press.

Hathaway, Oona A. 2002. "Do Human Rights Treaties Make a Difference?" Yale Law Journal 111 (8): 1935-2042.

He, Xin. 2009. "Routinization of Divorce Law Practice in China: Institutional Constraints' Influence on Judicial Behaviour." International Journal of Law, Policy and the Family 23 (1): 83-109.

- 2014. "Maintaining Stability by Law: Protest-Supported Housing Demolition Litigation and Social Change in China." Law and Social Inquirv 39 (4): 849-73.

_ 2017. “'No Malicious Incidents': The Concern for Stability in China's Divorce Law Practice." Social and Legal Studies 26 (4): 467-89.

$\mathrm{He}$, Xin, and Kwai Ng. 2013a. "In the Name of Harmony: The Erasure of Domestic Violence in China's Judicial Mediation." International Journal of Law, Policy and the Family 27 (1): 97-115.

. 2013b. "Pragmatic Discourse and Gender Inequality in China." Law and Society Review 47 (2): 279-310.

Heimer, Carol A. 1999. "Competing Institutions: Law, Medicine, and Family in Neonatal Intensive Care." Law and Societv Review 33 (1): 17-66.

Henan Provincial Academy of Social Sciences Research Team (河南省社会科学院课题组). 2017. “2016年河南法治建设状况与2017年展望 (Henan's Rule of Law Situation in 2016 and Outlook for 2017).” Pp. 1-19 in 河南法治发展报告 (Annual Report on Rule of Law Development in Henan), edited by Tongmin (丁同民) Ding and Linhai (张林海) Zhang. Beijing: 社会科学文献出版社 Social Sciences Academic Press.

Henan Provincial Bureau of Statistics. Various years. Henan Statistical Datasheet. Beijing: Zhongguo Tongji Chubanshe.

Honig, Emily, and Gail Hershatter. 1988. Personal Voices: Chinese Women in the 1980s. Stanford, CA: Stanford University Press.

Hou, Shumei, and Ronald C. Keith. 2012. "A New Prospect for Transparent Court Judgment in China?" China Information 26 (1): 61-86.

Htun, Mala, and S. Laurel Weldon. 2015. "Religious Power, the State, Women's Rights, and Family Law." Politics and Gender 11 (3): 451-77.

. 2018. The Logics of Gender Justice: State Action on Women's Rights around the World. Cambridge: Cambridge University Press.

Huang, Philip C. C. 2005. "Divorce Law Practices and the Origins, Myths, and Realities of Judicial 'Mediation' in China.” Modern China 31 (2): 151-203.

Hudson, Valerie M., Donna Lee Bowen, and Perpetua Lynne Nielsen. 2011. "What Is the Relationship between Inequity in Family Law and Violence against Women? Approaching the Issue of Legal Enclaves." Politics and Gender 7 (4): 453-92.

Information Office of the State Council. 2015. "Gender Equality and Women's Development in China." http://www.scio.gov.cn/zfbps/ndhf/2015/Document/1449894/Image /201509221449894_336090.pdf. Accessed March 11, 2019.

Inglehart, Ronald F., Eduard Ponarin, and Ronald C. Inglehart. 2017. "Cultural Change, Slow and Fast: The Distinctive Trajectory of Norms Governing Gender Equality and Sexual Orientation." Social Forces 95 (4): 1313-40.

Inglehart, Ronald, and Pippa Norris. 2003. Rising Tide: Gender Equality and Cultural Change around the World. Cambridge: Cambridge University Press.

Jiang, Feng (姜峰). 2015. “法院“案多人少”与国家治道变革: 转型时期中国的政治与司法忧思 (Courts' 'Many Cases, Few Judges' and National Governance Change: Political 
and Judicial Concerns in China's Era of Transformation).” 政法论坛(Tribune of Political Science and Law) 32 (3): 25-37.

Jiang, Yue (蒋月). 2009a. “改革开放三十年中国离婚法研究 (Looking Back and Ahead at China's Marriage Law after Thirty Years of Reform and Opening Up).” 法学家 (The Jurist) 1:63-84.

- 2009b. “论我国现行法定离婚理由立法主义 (China's Current Statutory Grounds for Divorce).” 东方法学 (Oriental Law) 4:17-28.

Jin, Ha. 2000. Waiting. New York: Vintage.

Kinkel, Jonathan J., and William J. Hurst. 2015. "The Judicial Cadre Evaluation System in China: From Quantification to Intra-State Legibility." China Quarterlv 224:933-54.

Landis, J. Richard, and Gary G. Koch. 1977. "The Measurement of Observer Agreement for Categorical Data." Biometrics 33 (1): 159-74.

Lee, Ching Kwan, and Yonghong Zhang. 2013. "The Power of Instability: Unraveling the Microfoundations of Bargained Authoritarianism in China." American Journal of Sociology 118 (6): 1475-1508.

$\mathrm{Li}$, Hongxiang (李洪祥). 2014. “离婚妇女婚姻家庭权益司法保障实证研究: 以吉林省中等发达 地区某基层法院2010-2012年抽样调查的离婚案件为对象 (Empirical Research on the Judicial Protection of Women's Marriage and Family Rights in Divorce).” 当代法学(Contemporary Law Review) 5:79-88.

Li, Jiahong (李桂红) and Feng (叶锋) Ye. 2015. “司法改革语境下司法辅助事务管理模式的构 建 (The Formation of Models for the Administration of Trial Work Assistance in the Conext of Judicial Reform).”上海政法学院学报(法治论丛) (Journal of Shanghai University of Political Science and Law [The Rule of Law Forum]) 4:102-12.

Li, Ke. 2015a. "Divorce, Help-Seeking, and Gender Inequality in Rural China." Ph.D. dissertation. Department of Sociology, Indiana University Bloomington. . 2015b. "'What He Did Was Lawful': Divorce Litigation and Gender Inequality in China." Law and Policy 37 (3): 153-79.

Li, Qiongyu (李琼宇), Shufen (刘淑芬) Liu, and Lin (杨林) Yang. 2013. “家庭暴力在离婚诉 讼案件中的认定与处断: 以贵阳市南明区人民法院2010 年度离婚案件为调查对象 (Affirming and Negating Domestic Violence in Divorce Litigation: An Investigation of Divorce Cases in the Nanming District People's Court of Guiyang City).” 哈尔滨学院学报(Journal of Harbin University) 34 (7): 32-36.

Li，Xuejing (李雪菁). 2014. “基层一线法官的职业困境与对策：以广西南宁市基层法院为例 (Frontline Judges' Plight and Countermeasures: The Case of a Basic-Level Court in Guangxi Province's City of Nanning).” 中外企业家 (Chinese and Foreign Entrepreneurs) 2:219-23.

Li, Yongjun (李拥军), and Fangfang (周芳芳) Zhou. 2018. “我国判决说理激励机制适用问题 之探讨 (On the Application of Incentive Mechanisms to Judgment Reasoning in China).” 法制与社会发展 (Law and Social Development) 3:57-69.

Liang, Xuguang (梁旭光). 1982. “反对轻率离婚 (Opposition to Frivolous Divorce).”道德与 文明 (Morality and Civilization), p. 19.

Liebman, Benjamin L. 2013. "Malpractice Mobs: Medical Dispute Resolution in China." Columbia Law Review 113:181-264.

_. 2014. "Legal Reform: China's Law-Stability Paradox." Daedalus 143 (2): 96-109. . 2015. "Leniency in Chinese Criminal Law? Everyday Justice in Henan." Berkeley Journal of International Law 33 (1): 153-222.

Liebman, Benjamin L., Margaret Roberts, Rachel E. Stern, and Alice Z. Wang. 2017. "Mass Digitization of Chinese Court Decisions: How to Use Text as Data in the Field of Chinese Law." 21st Century China Center Research Paper No. 2017-01. School of Global Policy and Strategy, University of California, San Diego; Columbia Public Law Research Paper No. 14-551. Columbia Law School, Columbia University, New York.

Lin, Xi (林曦), Xiaohong ( 卜晓虹) Bu, and Xiaoting (黎晓婷) Li. 2015. “司法担当论: 以离婚 纠纷案件为视角 (Engaged Justice: From the Perspective of Divorce Cases).” 治理研究 (Governance Studies) 3:123-28. 


\section{American Journal of Sociology}

Liu, Sida, and Terence C. Halliday. 2016. Criminal Defense in China: The Politics of Lawyers at Work. Cambridge and New York: Cambridge University Press.

Liu, Yahui (刘亚辉). 2016. “省十二届人大五次会议举行第二次大会 (Second Meeting of the Fifth Session of the 12th Henan Provincial People's Congress).” 河南日报 (Henan Daily), February 4, p. 1.

Liu, Ye, John Stillwell, Jianfa Shen, and Konstantinos Daras. 2014. "Interprovincial Migration, Regional Development and State Policy in China, 1985-2010.” Applied Spatial Analysis and Policy 7 (1): 47-70.

$\mathrm{Liu}, \mathrm{Yu}$ (刘瑜). 2011. “被离婚”奇案, 还是'再离婚'闹剧? ———钢铁大王'杜双华家里那本难念 的经 (A Case of 'Unwittingly Divorced' Or a Farce of 'Re-Divorced'? Steel Magnate Du Shuanghua's Family Skeleton in the Closet).”民主与法制 (Democracy and Legal System) 16:38-41.

Long, J. Scott, and Jeremy Freese. 2014. Regression Models for Categorical Dependent Variables Using Stata, 3rd ed. College Station, TX: Stata Press.

Long, J. Scott, and Sarah A. Mustillo. 2018. "Using Predictions and Marginal Effects to Compare Groups in Regression Models for Binary Outcomes." Sociological Methods and Research. https://doi.org/10.1177/0049124118799374.

Lu, Pin. 2018. “Two Years On: Is China's Domestic Violence Law Working?” https:// www.amnesty.org/en/latest/campaigns/2018/03/is-china-domestic-violence-law -working/. Accessed June 21, 2019.

Luo, Ling (罗玲). 2016. “裁判离婚理由影响因素实证研究: 以 2010-2011年河南省的部分离 婚纠纷案件判决文书为样本 (An Empirical Study at the Factors Affecting the Legal Grounds for Divorce: A 2010-11 Sample of Divorce Judgments from Henan Province.” 中华女子学院学报 (Journal of China Women's University) 1:14-23.

Ma, Chao (马超), Xiaohong (于晓虹) Yu, and Haibo (何海波) He. 2016. “大数据分析:中国司 法裁判文书上网公开报告. (Big Data Analysis: A Report of China Judgements Online). 中国法律评论 (China Law Review) 4:195-246.

Ma, Mingyang (马名扬). 2018. “离婚冷静期通知书, 只想让你更懂得珍惜 (The Divorce CoolingOff Notice Is Only to Help You Cherish What You Have).”婚姻与家庭(社会纪实) (Marriage and Family) 2:16-18.

Ma, Yinan (马忆南). 2006. “婚姻法第32条实证研究 (Empirical Research on Article 32 of the Marriage Law).” 金陵法律评论 (Jin Ling Law Review) 1:20-27.

Ma, Yinan (马忆南), and Ling (罗玲) Luo. 2014. “裁判离婚理由立法研究 (Research on Court Holdings in Divorce Rulings).” 法学论坛 (Legal Forum) 29 (4): 34-44.

McHugh, Marry L. 2012. "Interrater Reliability: The Kappa Statistic." Biochemia Medica 22 (3): 276-82.

Merry, Sally Engle. 2006. Human Rights and Gender Violence: Translating International Law into Local Justice. Chicago: University of Chicago Press.

Meyer, John W. 2010. "World Society, Institutional Theories, and the Actor." Annual Review of Sociology 36 (1): 1-20.

Meyer, John W., John Boli, George M. Thomas, and Francisco O. Ramirez. 1997. "World Society and the Nation-State.” American Journal of Sociology 103 (1): 144-81.

Meyer, John W., and Brian Rowan. 1977. "Institutionalized Organizations: Formal Structure as Myth and Ceremony." American Journal of Sociology 83 (2): 340-63.

Michelson, Ethan. 2006. "The Practice of Law as an Obstacle to Justice: Chinese Lawyers at Work." Law and Societv Review 40 (1): 1-38.

2007. "Lawyers, Political Embeddedness, and Institutional Continuity in China's Transition from Socialism." American Journal of Sociologv 113 (2): 352 414.

Ministry of Civil Affairs of China. 2018. “2017 年社会服务发展统计公报 (2017 Social Services Development Statistical Report).” http://www.mca.gov.cn/article/sj/tjgb/201808 /20180800010446.shtml. Accessed June 13, 2019.

- Various years. China Civil Affairs Statistical Yearbook (中国民政统计年鉴). Beijing: Zhongguo Tongji Chubanshe. 
Minzner, Carl. 2009. "Judicial Disciplinary Systems for Incorrectly Decided Cases: The Imperial Chinese Heritage Lives On.” New Mexico Law Review 39 (1): 63-87.

Minzner, Carl F. 2011. "China's Turn against Law." American Journal of Comparative Law 59 (4): 935-84.

Mize, Trenton. 2019. "Best Practices for Estimating, Interpreting, and Presenting Nonlinear Interaction Effects." Sociological Science 6:81-117.

Mo, Li. 2017. "Trends in the Divorce Rate and Its Regional Disparity in China." Journal of Comparative Familv Studies 48 (4): 383-94.

Myers, Steven Lee, and Olivia Mitchell Ryan. 2018. "Burying 'One Child' Limits, China Pushes Women to Have More Babies.” New York Times, August 11.

Negro, Giacomo, and Wesley Longhofer. 2018. "World Society, Legal Formalism, and Execution of Legal Procedures." Social Forces 97 (2): 649-73.

Ningbo City Yinzhou District People’s Court (宁波市鄞州区人民法院). 2014. “离婚纠纷案件审 判白皮书 2009-2012年 (Divorce Dispute Case Trials White Paper 2009-2012).” http:// www.nbyzfy.gov.cn/art/2014/7/11/art_3478_229265.html. Accessed June 27, 2019.

Pache, Anne-Claire, and Filipe Santos. 2013. "Embedded in Hybrid Contexts: How Individuals in Organizations Respond to Competing Institutional Logics." Pp. 3-35 in Institutional Logics in Action, Part B, edited by Michael Lounsbury and Eva Boxenbaum. Bingley, UK: Emerald.

Palmer, Michael. 1995. "The Re-Emergence of Family Law in Post-Mao China: Marriage, Divorce and Reproduction." China Ouarterlv 141:110-34.

Pierotti, Rachael S. 2013. "Increasing Rejection of Intimate Partner Violence." American Sociological Review 78 (2): 240-65.

Pope, Shawn, and John W. Meyer. 2016. "Local Variation in World Society: Six Characteristics of Global Diffusion." European Journal of Cultural and Political Sociologv 3 (2-3): 280-305.

Raynard, Mia, Michael Lounsbury, and Royston Greenwood. 2013. "Legacies of Logics: Sources of Community Variation in CSR Implementation in China." Pp. 243-76 in Institutional Logics in Action, Part A, edited by Michael Lounsbury and Eva Boxenbaum. Bingley, UK: Emerald.

Research Office of the Nanjing Municipal Intermediate Court. 1987. “谈判决不准离婚 (A Discussion of Adjudicated Denials of Divorce Petitions).” 人民司法 (People's Judicature) 10:16-18.

Ridgeway, Cecilia L. 2011. Framed by Gender: How Gender Inequality Persists in the Modern World. Oxford and New York: Oxford University Press.

Rong, Weiyi (荣维毅). 2016. “反对针对妇女暴力领域法律政策回顾分析 (A Review and Analysis of Laws and Policies to Combat Violence against Women).” Pp. 203-14 in 20132015 年: 中国性别平等与妇女发展报告 (Annual Report on Gender Equality and Women's Development in China [2013-2015]), edited by Lin (谭琳) Tan. Beijing: 社会科学文献出 版社 Social Sciences Academic Press.

Runge, Robin. 2015. "Operating in a Narrow Space to Effect Change: Development of a Legal System Response to Domestic Violence in China.” Pp. 31-42 in Comparative Perspectives on Gender Violence: Lessons from Efforts Worldwide, edited by Rashmi Goel and Leigh Goodmark. New York: Oxford University Press.

Schofer, E., and A. Hironaka. 2005. "The Effects of World Society on Environmental Protection Outcomes." Social Forces 84 (1): 25-47.

Schofer, Evan, Ann Hironaka, David John Frank, and Wesley Longhofer. 2012. "Sociological Institutionalism and World Society." Pp. 57-68 in The Wiley-Blackwell Companion to Political Sociology, edited by Edwin Amenta, Kate Nash, and Alan Scott. Chichester, UK: Wiley-Blackwell.

Stanko, Elizabeth Anne. 1982. "Would You Believe This Woman? Prosecutorial Screening for 'Credible' Witnesses and a Problem of Justice." Pp. 63-82 in Judge, Lawyer, Victim, Thief: Women, Gender Roles, and Criminal Justice, edited by Nicole Hahn Rafter and Elizabeth Anne Stanko. Boston: Northeastern University Press. 


\section{American Journal of Sociology}

Steensland, Brian. 2006. "Cultural Categories and the American Welfare State: The Case of Guaranteed Income Policy.” American Journal of Sociologv 111 (5): 1273-1326.

Sun, Bo (孙波). 2010. “离婚案件缺席审判的思考 (Reflections on In Absentia Divorce Trials).” 大众商务 (Popular Business) 116:264.

Sun, Yong (孙勇). 2006. “公告离婚的适用与完善 (The Application and Improvement of In Absentia Public Notice Divorce).”理论月刊(Theory Monthly) 1:121-23.

Tan, Dexiu (谭德修), and Yonghong (王永红) Wang. 2011. “公告离婚适用的困境与出路一 兼评我国《婚姻法》第32 条第4 款之不足 (Dilemmas and Remedies in the Application of Public Notice Divorces: A Commentary on the Deficiencies of Article 32, Item 4 of the Marriage Law).” 湖南科技学院学报 (Journal of Hunan University of Science and Engineering) 32 (8): 115-18.

Tang, Wenfang, and William L. Parish. 2000. Chinese Life under Reform: The Changing Social Contract. Cambridge: Cambridge University Press.

Tang, Yingmao, and John Zhuang Liu. 2019. "Mass Publicity of Chinese Court Decisions: Market-Driven or Authoritarian Transparency?" China Review 19 (2): 15-40.

Tao, Jian (陶建), and Wei (卢茜) Lu. 2012. “农村离婚率上升的成因及法律思考 (Causes of and Legal Considerations for the Rise of Rural Divorce).” 法制与社会 (Legal System and Society) 19 (7): 65-66.

Thornton, Arland, and Yu Xie. 2016. "Developmental Idealism in China." Chinese Journal of Sociology 2 (4): 483-96.

Thornton, Patricia H., William Ocasio, and Michael Lounsbury. 2012. The Institutional Logics Perspective: A New Approach to Culture, Structure, and Process. New York: Oxford University Press.

Tian, Xiangyu (田祥玉). 2016. “离婚应该慢慢来 (Take It Slowly with Divorce).” 婚姻与家 庭 (社会纪实) (Marriage and Family) 8:25-27.

True, Jacqui, and Michael Mintrom. 2001. "Transnational Networks and Policy Diffusion: The Case of Gender Mainstreaming." International Studies Ouarterly 45 (1): 27-57.

Wang, Cheng-Tong Lir, and Evan Schofer. 2018. "Coming out of the Penumbras: World Culture and Cross-National Variation in Divorce Rates." Social Forces 97 (2): 675704.

Wang, Jian. 2013. "To Divorce or Not to Divorce: A Critical Discourse Analysis of CourtOrdered Divorce Mediation in China." International Journal of Law, Policy and the Familv 27(1):74-96.

Wang, Yuhua. 2014. Tying the Autocrat's Hands: The Rise of the Rule of Law in China. Cambridge and New York: Cambridge University Press.

Wang, Yuyan (王玉燕). 2012. “浅议公告送达在离婚案件中的适用 (A Discussion of the Application of Public Notice Service in Divorce Cases).” 法制与社会 (Legal System and Society) 1:119-20.

Welzel, Christian. 2013. Freedom Rising: Human Empowerment and the Ouest for Emancipation. Cambridge and New York: Cambridge University Press.

Wimmer, Andreas. 2001. "Globalizations Avant La Lettre: A Comparative View of Isomorphization and Heteromorphization in an Inter-Connecting World." Comparative Studies in Society and History 43 (3): 435-66.

Woo, Margaret. 2001. "Review of Neil J. Diamant's Revolutionizing the Family: Politics, Love, and Divorce in Urban and Rural China, 1949-1968." American Journal of Sociology 107 (1): 256-57.

Wotipka, Christine Min, and Francisco O. Ramirez. 2008. "World Society and Human Rights: An Event History Analysis of the Convention on the Elimination of All Forms of Discrimination Against Women." Pp. 303-43 in The Global Diffusion of Markets and Democracy, edited by Beth A. Simmons, Frank Dobbin, and Geoffrey Garrett. Cambridge and New York: Cambridge University Press.

Xiao, Jianfei (肖建飞), Yanwen (马艳雯) Ma, and Danting (妥丹婷) Tuo. 2014. “婚姻家庭纠 纷审判中的裁判行为分析 (An Analysis of Judicial Decisions in Family Dispute Litigation).”边疆经济与文化 (Border Economy and Culture) 12:61-63. 
$\mathrm{Xu}$, Anqi (徐安琪). 2007. “离婚与女性地位及权益之探讨 (Exploring Divorce and the Status, Rights, and Interests of Women).” 浙江学刊 (Zhejiang Academic Journal) 1:198206.

Xu, Chunbin (许春涁). 2012. “分居认定标准研究一以 2009-2010 年河南省部分基层法院离 婚纠纷案件判决书为样本 (Standards for Identifying Separation: An Empirical Study on Basic-Level Courts' Granting Divorce in Henan Province in 2009 and 2010).” 中华女子学院学报 (Journal of China Women's University) 1:38-44.

Yi, Xingming (易兴明), and Daocai (童道才) Tong. 1998. “谈判决不准离婚的违法性 (A Discussion of the Illegality of Adjudicated Denials of Divorce Petitions).” 人民司法(People's Judicature) 1998 (10): 38-39.

Yu, Jia, and Yu Xie. 2015. "Cohabitation in China: Trends and Determinants." Population and Development Review 41 (4): 607-28.

Yu, Jianhua (余建华), and Huanyan (孟焕良) Meng. 2016. “浙江全力打造·智慧法院”获点赞 (Zhejiang Praised for Its Full Commitment to Building a 'Smart Court').” 人民法院报 (People's Court Daily), February 6, p. 1.

Zeng, Qiong (曾琼). 2008. “论离婚案件中的公告送达 (On Public Notice Service of Process in Divorce Cases).” 学海 (Academia Bimestrie) 2:161-65.

Zhang, Jianyuan (张剑源). 2018. “家庭暴力为何难以被认定? 以涉家暴离婚案件为中心的实证 研究 (Why Is Family Violence Difficult to Affirm? An Empirical Study Focusing on Divorce Cases Related to Family Violence).”山东大学学报(哲学社会科学版) (Journal of Shandong University [Philosophy and Social Sciences]) 4:103-11.

Zhang, Xuejun (张学军). 2009. “婚姻法学研究三十年 (Thirty Years of Legal Research on Marriage Law).” 法学杂志 (Law Science Magazine) 2:26-29.

Zhang, Yun (章蕴). 1957. “勤俭建国勤俭持家为建设社会主义而奋斗 (Diligently Build the Nation and Diligently Grasp the Family for the Struggle of Socialist Construction: Zhang Yun's Speech to the Third National Women's Conference).”人民日报(People's Daily), September 9, p. 4.

Zhao, Jianwen (赵建文). 2016. “中国人权报告:性别平等与妇女发展状况 (China Human Rights Report: Gender Equality and Women's Development).” Pp. 47-57 in 中国法 治发展报告 (Annual Report on China's Rule of Law), edited by Lin (李林) Li and He (田禾) Tian. Beijing: 社会科学文献出版社 Social Sciences Academic Press.

Zhao, Mingxing (赵明星). 2018. “论离婚诉讼的公告送达制度 (On the Public Notice Service of Process System in Divorce Litigation).” 思想政治与法律研究 (Research on Ideology, Politics, and Law) 9:187.

Zhao, Ruohui, and Hongwei Zhang. 2017. "Family Violence and the Legal and Social Responses in China.” Pp. 189-206 in Global Responses to Domestic Violence, edited by Eve S. Buzawa and Carl Buzawa. Basel: Springer.

Zheng, Chunyan, Jiahui Ai, and Sida Liu. 2017. "The Elastic Ceiling: Gender and Professional Career in Chinese Courts." Law and Societv Review 51 (1): 168-99.

Zhou, Jiao (周姣). 2018. “关于离婚冷静期制度的思考 (Thoughts on a System for Divorce Cooling-Off Periods).” 法制与社会 (Legal System and Society) 1:35-36.

Zhou, Viola. 2017. "More Divorces Combined with Fewer Marriages Seen as Threat to Family Life." South China Morning Post, September 6, p. 5. 